\title{
Note
}

\section{Private Voucher Schools and the First Amendment Right To Discriminate}

\author{
Michael Kavey
}

\section{INTRODUCTION}

At the end of its 2001 Term, the Supreme Court settled one of the most contentious educational debates in recent history, ruling in Zelman $v$. Simmons-Harris that the inclusion of religious schools in a state school voucher program did not violate the Establishment Clause of the Constitution. ' There are, however, complex constitutional questions about vouchers that linger in Zelman's wake. This Note addresses one such issue that has only just begun to receive scholarly attention: Can states require private voucher schools-including religious schools-to comply with antidiscrimination policies, or would the enforcement of those policies violate the First Amendment rights of the schools? ${ }^{2}$ For example, could a state require a private school to admit racial minorities, women, and gays and lesbians as a condition for eligibility in a state voucher program? What

1. 536 U.S. 639 (2002).

2. Recent work on this topic includes Jesse H. Choper, Federal Constitutional Issues, in SCHOOl ChOICE AND SOCIAL CONTROVERSY: POLITICS, POLICY, AND LAW 235, 254-59 (Stephen D. Sugarman \& Frank R. Kemerer eds., 1999); Ira C. Lupu \& Robert W. Tuttle, Zelman's Future: Vouchers, Sectarian Providers, and the Next Round of Constitutional Battles, 78 NOTRE DAME L. REV. 917, 972-82 (2003); Mark Tushnet, Vouchers After Zelman, 2002 SUP. CT. REV. 1, 22-29; and Bonnie Daboll, Note, School-Choice Legislation: Constitutional Limitations on State Regulation of Participating Parochial Schools After Zelman v. Simmons-Harris, 55 FLA. L. REV. 711, 725-28 (2003). See generally MARK G. YUDOF ET AL., EDUCATIONAL POLICY AND THE LAW 75-98 (4th ed. 2002) (discussing legal issues surrounding discrimination in private education). 
if the school administrators object on principle-perhaps religious principle - to racial integration, coeducational schooling, or homosexuality? Doesn't the First Amendment protect the schools' views?

The Supreme Court's jurisprudence does not provide easy answers to these questions, and the relevant body of case law is inconsistent. This Note seeks to make sense of the doctrine and to demonstrate that, as applied to private voucher schools, antidiscrimination laws can-and should-survive a First Amendment challenge. ${ }^{3}$

Part I provides a brief overview of the current status of voucher laws and proposals, and discusses the opposition of civil rights organizations to these laws. Part II then analyzes the free speech problems that may arise if states require voucher schools to adhere to antidiscrimination norms. I argue first that voucher programs are a form of "government speech through private actors," and that in such cases the Free Speech Clause does not preclude states from making viewpoint-based distinctions. The remainder of Part II deals with the possibility that courts will reject this analysis. I discuss the various constitutional tests to which courts may subject antidiscrimination requirements, and I argue that antidiscrimination policies should survive any of them. Because the Free Speech Clause poses the most complex problems for antidiscrimination policies, the bulk of the Note centers on this issue.

Part III addresses issues raised by the Free Exercise and Establishment Clauses, and argues that religious voucher schools can also be bound to antidiscrimination policies without violating the schools' First Amendment freedoms. The only exception would be for clerical teacher employment disputes at religious schools; such suits are nonjusticiable due to a mixture of Free Exercise and Establishment Clause concerns. ${ }^{4}$

3. This Note deals exclusively with private voucher schools. Charter schools-another form of school choice-are considered public schools, and thus present an entirely different range of constitutional questions.

4. The focus of this Note is on the First Amendment rights of the voucher schools that wish to discriminate against certain groups of children or teachers. The question of whether voucher antidiscrimination laws violate the constitutional rights of parents is entirely separate. The Court has recognized a parental right under the Fourteenth Amendment to enroll a child in a private-as opposed to a public-school. See Pierce v. Soc'y of the Sisters of the Holy Names of Jesus and Mary, 268 U.S. 510 (1925). But Pierce did not create an expansive right, and the Court made the limits on that right patently clear from the very beginning:

No question is raised conceming the power of the State reasonably to regulate all schools, ... to require that ... teachers shall be of good moral character and patriotic disposition, that certain studies plainly essential to good citizenship must be taught, and that nothing be taught which is manifestly inimical to the public welfare.

Id. at 534. Subsequent cases have left equally clear that parents do not have a right to provide any sort of education they please, much less a right to have their state-funded school discriminate against people that the parents disfavor. See Runyon v. McCrary, 427 U.S. 160, 177 (1976) (stressing "the limited scope of Pierce, which simply affirmed the right of private schools to exist and to operate" (citation omitted)); see also Wisconsin v. Yoder, 406 U.S. 205, 239 (1972) (White, J., concurring) (explaining that Pierce "lends no support to the contention that parents may replace state educational requirements with their own idiosyncratic views"). It is therefore 


\section{VOUCHER SCHOOLS AND THE OPPOSITION OF CIVIL RIGHTS GROUPS: AN OVERVIEW}

Though programs may differ in many ways, the basic structure of a voucher program is simple: The state offers parents-typically only low-income parents-government vouchers that can be used to pay for their children's education at eligible private schools within the state. The state pays for the vouchers with the public tax dollars that would otherwise pay for those students' public education. The flow of money from the government to the private schools is indirect: The voucher money passes first into the hands of parents, who then direct the funds to the private schools of their choice. ${ }^{5}$

The voucher movement has produced odd coalitions. Some liberals and advocates for minority youth, frustrated by the failures of public schools, have joined with conservatives eager to secure public funding for religious education to form a unique and diverse political coalition. In opposition stand mainstream civil rights groups, teachers' unions, and suburban parents wishing to maintain the status quo. ${ }^{6}$

Advocates claim that vouchers are one solution to the failures of public education and that they rightly give poor parents the same options that wealthy parents already have. ${ }^{7}$ Opponents claim that vouchers provide only a false hope, drain money from financially strapped public schools, and facilitate racial segregation. ${ }^{8}$

In opposing vouchers, a wide array of civil rights and educational groups have also expressed concern that participating schools will be free to discriminate against disfavored groups, such as racial and religious minorities, women, and gays and lesbians. Organizations such as the National Education Association, the National PTA, the American Civil

not surprising that the scholars addressing the voucher antidiscrimination question have generally focused on the rights of schools, not parents. See Lupu \& Tuttle, supra note 2, at 972-82; Tushnet, supra note 2, at 22-29; Daboll, supra note 2, at 725-28. But see Choper, supra note 2, at 254-59 (arguing that in some circumstances regulation of voucher schools could violate parental rights).

5. The indirect nature of the funding is important in ensuring compliance with the Establishment Clause, but it does not change the fact that the schools, not the parents, are the entities regulated by antidiscrimination law. See infra note 63 .

6. For discussions of the political coalitions in the voucher movement, see James E. Ryan \& Michael Heise, The Political Economy of School Choice, 111 YALE L.J. 2043, 2078-85 (2002). See also TERRY M. MOE, SCHOOLS, VOUCHERS, AND THE AMERICAN PUBLIC 254-55 (2001).

7. See, e.g., KRISTA KAFER, HERITAGE FOUND., D.C. SCHOlarSHIP PROPOSAL WOULD GIVE STUDENTS ACCESS TO QUALITY SCHOOLS (2003), http://www.heritage.org/Research/ Education/Bg1671.cfm.

8. See, e.g., TAMMY JOHNSON et AL., APPLIED RESEARCH CTR., VOUChers: A TRAP, NOT A CHOICE: CALIFORNIA SCHOOL VOUCHERS WILl INCREASE RACIAL INEQUALITY (2000), at http://www.arc.org/erase/vouchers/voucherreport.pdf; Jay Matthews, Bush Pushes Vouchers, D.C. Charters, WASH. POST, July 2, 2003, at A1; People for the Am. Way, PFAW on Capitol Hill: Vouchers vs. Public Education, http://www.pfaw.org/pfaw/general/default.aspx?oid=9855 (last visited Oct. 15, 2003). 
Liberties Union, the National Alliance of Black School Educators, and the Leadership Conference on Civil Rights have criticized voucher legislation for authorizing government-funded discrimination. ${ }^{9}$ The Gay, Lesbian and Straight Education Network has warned that under most voucher programs, "a private school could theoretically expel a student because of his or her sexual orientation," and that participating schools "would not be required to protect any LGBT [lesbian, gay, bisexual, or transgender] student from in-school harassment."10 The Anti-Defamation League has adopted a particularly alarmist tone, claiming that "the proud legacy of Brown v. Board of Education may be tossed away as tax dollars are siphoned off to deliberately segregated schools." 11

Given the current state of voucher programs and proposals, the fears expressed by these organizations should come as no surprise. Most voucher legislation-whether already enacted or only proposed-contains only limited antidiscrimination protections. Consider, for example, the four existing voucher statutes that allow for the participation of religious schools. Ohio's statute only requires that participating schools "not discriminate on the basis of race, religion, or ethnic background." 12 It further mandates that schools not "teach hatred of any person or group on the basis of race, ethnicity, national origin, or religion." ${ }^{13}$ Florida's program requires schools to comply with Title VI, which only bans discrimination on the basis of race, color, or national origin. ${ }^{14}$ Wisconsin's voucher statute contains the same requirement. ${ }^{15}$ Civil rights advocates in Wisconsin have been unsuccessful in their repeated efforts to include a more comprehensive antidiscrimination policy in that state's voucher law, despite the fact that Wisconsin public schools are held to one of the most expansive antidiscrimination laws in the nation. ${ }^{16}$ Colorado's voucher law-the most

9. See Letter from the American Association of School Administrators et al., National Coalition for Public Education, to the Committee on Education and the Workforce, U.S. House of Representatives (July 23, 2002), http://www.aclu.org/ReligiousLiberty/ ReligiousLiberty.cfm? $\mathrm{ID}=10550 \& \mathrm{c}=140$ (stating that a bill to establish vouchers in the District of Columbia "authorizes federally funded discrimination").

10. Gay, Lesbian \& Straight Educ. Network, PARENTAL "ChOice," SCHOOL "Choice," AND SCHOOL VOUCHERS 121, http://www.glsen.org/binary-data/GLSEN_ARTICLES/pdf_file/ 695.pdf (last visited Oct. 15, 2003).

11. Anti-Defamation League, Vouchers Undermine Public Schools, at http://www.adl.org/ vouchers/vouchers_public_schools.asp (last visited Nov. 7, 2003).

12. OHIO REV. CODE ANN. $\S 3313.976(\mathrm{~A})(4)$ (Anderson 2002).

13. Id. $\$ 3313.976(\mathrm{~A})(6)$.

14. See Fla. STAT. ANN. $\S 1002.38(4)$ (c) (West, WESTLAW through 2003 Reg. Sess. \& Spec. Sess. A-D) (requiring compliance with 42 U.S.C. $\S 2000$ d (2000)).

15. See WIS. STAT. ANN. $\$ 119.23(2)(a)(4)$ (West 1999).

16. See id. $\S 118.13(1)$ (prohibiting discrimination against students in public schools on the basis of "sex, race, religion, national origin, ancestry, creed, pregnancy, marital or parental status, sexual orientation or physical, mental, emotional or learning disability"); see also People for the Am. Way, Facts About Vouchers, at http://www.pfaw.org/pfaw/general/default.aspx?oid=5473 (last visited Nov. 7, 2003) (describing failed attempts to expand the antidiscrimination policy covering voucher schools in Wisconsin). 
recently enacted of voucher laws-bans discrimination in participating schools only on the basis of "race, color, religion, national origin, or disability." A vague but potentially expansive provision of Colorado's law also bans schools from "teach[ing] hatred of any person or group." 18

Most proposed voucher bills include civil rights protections that would ban discrimination by voucher schools on the basis of race and national origin but do not contain provisions banning discrimination based on religion or sexual orientation. ${ }^{19}$ One obvious explanation for this pattern is that discrimination against religious groups or gays and lesbians is more often considered justified by religious teachings, and legislators wish to respect religious schools' rights to free exercise of religion. Another obvious explanation for the exclusion of sexual orientation is simply that in many parts of the country such discrimination is still socially and politically acceptable, regardless of whether there is a religious motivation. Despite these obstacles, legislators concerned about civil rights have not given up on efforts to include classifications like religion and sexual orientation in voucher laws. $^{20}$

Voucher legislation also tends not to ban discrimination based on sex, ${ }^{21}$ perhaps because of the common-though certainly not universalacceptance of single-sex schools as consistent with antidiscrimination norms. Some voucher legislation not only lacks civil rights protections altogether, but also includes provisions that could, among other things, affirmatively protect a school's "right" to discriminate. For example, voucher legislation proposed in Kansas includes a provision stating that "[n]othing in this act shall be applied or construed in any manner so as to regulate or prohibit free exercise in matters of curriculum, creed or practice of any nonpublic Kansas school of choice."22

Opposition to vouchers is driven not only by legislators' tendency to exclude comprehensive antidiscrimination provisions from voucher proposals, but also by a fear that private schools would be constitutionally exempted from antidiscrimination policies even if legislatures attempted to impose them. The First Amendment protects expressive association and, as

17. COLO. REV. STAT. ANN. $\$ 22-56-106$ (b) (West Supp. 2003).

18. Id. § 22-56-106(c).

19. See, e.g., H.R. 1691, 84th Gen. Assem., Reg. Sess. (Ark. 2003) (banning discrimination by participating voucher schools on the basis of race, color, or national origin); H.R. 1771, 2003 Leg., Reg. Sess. (La. 2003) (banning discrimination by participating voucher schools on the basis of race, religion, or ethnicity); H.R. 27, 45th Leg., 2d Reg. Sess. (N.M. 2002) (same).

20. See H.R. 19, 2003 Leg., 105th Reg. Sess. (Fla. 2003) (banning harassment and discrimination based on race, color, religion, national origin, marital status, sex or gender, disability, or sexual orientation); S. 274, 124th Gen. Assem., Reg. Sess. (Ohio 2002) (banning discrimination by participating voucher schools on the basis of race, religion, ethnicity, gender, marital status, pregnancy, sexual orientation, or disability); Assem. Res. 716, 95th Leg., Reg. Sess. (Wis. 2001) (same).

21. See sources cited supra notes 12, 14-15, 17-19.

22. S. 211, 80th Leg., Reg. Sess. (Kan. 2003). 
the Supreme Court has recently held, this may include discriminatory conduct. ${ }^{23}$ Would voucher schools therefore be constitutionally immune from antidiscrimination regulations? In addressing this issue, I turn first to the Free Speech Clause.

\section{FREE SPEECH AND ANTIDISCRIMINATION POLICIES}

\section{A. Overview of the Free Speech Problem}

Though the weight of the precedent is now unclear, the Supreme Court has upheld the government's authority to impose antidiscrimination policies on private schools. Language from two opinions in particular would seem to suggest, at first, that there is no conflict at all between free speech rights and a requirement that voucher schools adhere to antidiscrimination norms.

In Runyon v. McCrary, two African-American students challenged a private school's policy of denying admission to blacks. ${ }^{24}$ The Supreme Court held that 42 U.S.C. $\S 1981$ prohibited private, commercially operated, nonsectarian schools from discriminating on the basis of race in admissions. In so holding, the Court flatly rejected the school's contention that $\S 1981$, as applied, violated its constitutionally protected rights of free association:

[T]he Court has recognized a First Amendment right to engage in association for the advancement of beliefs and ideas ....

From this principle it may be assumed that parents have a First Amendment right to send their children to educational institutions that promote the belief that racial segregation is desirable, and that the children have an equal right to attend such institutions. But it does not follow that the practice of excluding racial minorities from such institutions is also protected by the same principle.... [T]he Constitution ... places no value on discrimination, and while [i]nvidious private discrimination may be characterized as a form of exercising freedom of association protected by the First Amendment ... it has never been accorded affirmative constitutional protections. ${ }^{25}$

Eight years later, the Court reaffirmed this principle in Hishon $v$. King \& Spalding, stating that "[t]here is no constitutional right... to discriminate in the selection of who may attend a private school or join a

23. See Boy Scouts of Am. v. Dale, 530 U.S. 640 (2000).

24. 427 U.S. 160 (1976).

25. Id. at 175-76 (second and third alterations in original) (internal quotation marks and citations omitted). 
labor union." ${ }^{26}$ Hishon and Runyon seem to establish quite clearly that antidiscrimination laws can be constitutionally applied to voucher schools. However, subsequent developments in First Amendment law have left the force of these decisions unclear. The Runyon Court emphatically stated that "[i]nvidious private discrimination" had "never been accorded affirmative constitutional protections." ${ }^{27}$ But this is simply no longer true. In 2000, the Supreme Court held that the free speech right of expressive association exempted the Boy Scouts of America from New Jersey's public accommodations law banning discrimination on the basis of sexual orientation. ${ }^{28}$ Though the majority made no mention of Runyon, the opinion is in obvious tension with Runyon's First Amendment holding. In Boy Scouts of America v. Dale, the Boy Scouts terminated the adult membership of an openly gay Eagle Scout, James Dale, on the ground that the organization "specifically forbid[s] membership to homosexuals." 29 The Supreme Court of New Jersey had held that scouting constituted a public accommodation subject to the state's antidiscrimination law and had rejected the Boy Scouts' claim that the First Amendment exempted it as a private organization from that law. ${ }^{30}$ The Supreme Court reversed. The Court found that the Boy Scouts engaged in expressive association and that its membership policy was protected by the First Amendment. Chief Justice Rehnquist, writing for the majority, accorded deference to the Scouts' assertion that Dale's inclusion in the organization would significantly and adversely affect the Scouts' message. ${ }^{31}$ Given the effects of Dale's membership on the Scouts' message and purpose, the organization had a constitutional right to exclude him. As the Chief Justice wrote, "The forced inclusion of an unwanted person in a group infringes the group's freedom of expressive association if the presence of that person affects in a significant way the group's ability to advocate public or private viewpoints. ${ }^{\prime 32}$ It is still unclear how broad Dale's reach will be. If it does extend into the realm of private schools, the consequences for antidiscrimination laws and voucher programs may be enormous. Voucher schools, like the Boy Scouts, may argue that their discriminatory practices entail the constitutionally protected expression of their viewpoints, and that this free expression may not be burdened or disfavored by the government.

In responding to this Free Speech Clause problem, I divide the analysis into several parts. The first part, Section II.B, addresses the question of

26. 467 U.S. 69,78 (1984).

27. 427 U.S. at 176 (alteration in original) (internal quotation marks omitted).

28. Dale, 530 U.S. 640.

29. Id. at 645 (internal quotation marks omitted).

30. See Dale v. Boy Scouts of Am., 734 A.2d 1196, 1222-29 (N.J. 1999), rev'd, 530 U.S. 640.

31. Dale, 530 U.S. at 653.

32. Id. at 648 . 
whether close First Amendment scrutiny can be avoided by placing voucher programs into the special category of "government speech through private actors." I answer this question in the affirmative. Because the government funds private schools for the purpose of communicating government messages, the state has significant leeway in choosing which activities to subsidize or exclude from its programs.

Sections II.C, II.D, and II.E of the free speech analysis address what could happen if courts reject this government-speech argument. Section II.C analyzes the possibility that courts will designate voucher programs as limited public or nonpublic fora. Section II.D addresses whether antidiscrimination requirements could be subject to heightened scrutiny, and more importantly, whether they could survive such scrutiny. Section II.E discusses an alternative, deferential approach that the Supreme Court has begun to take in certain kinds of government-funding cases-an approach that allows for content- and viewpoint-based distinctions by the government. Finally, Section II.F briefly compares these approaches and argues that the first and last are the most sensible routes to follow.

\section{B. Voucher Programs as Government Speech}

The fact that regulations might apply only to those private entities receiving state funds does not immunize the regulations from constitutional scrutiny. The Supreme Court has held that the First Amendment applies in the subsidy context, though the rules are somewhat different. ${ }^{33}$ On the other hand, if it is the government that is speaking, a completely different analysis controls the inquiry, even if the government speaks through private actors. But if private actors can engage in government speech, how are we to distinguish between government speech and private speech?

To understand the answer to this question, we must delve into the thick "morass" 34 of the unconstitutional conditions doctrine, an area of law that is "notorious" for its "haphazard inconsistencies." 35 The central principle in this doctrine is that states may not condition a government benefit on the relinquishment of a constitutional right. Such conditions are especially pernicious when combined with content-based or viewpoint-based discrimination. A particularly egregious example would be a requirement that a person forego his right to express views critical of the government as a condition for receiving a tax exemption. ${ }^{36}$ Despite the apparent clarity of this rule, the Supreme Court did uphold a blatant viewpoint-based condition on government subsidies in one landmark First Amendment case that the

33. See Nat'l Endowment for the Arts v. Finley, 524 U.S. 569, 587 (1998).

34. Tushnet, supra note 2, at 27 n.93.

35. Robert Post, Subsidized Speech, 106 Y ALE L.J. 151, 152 (1996).

36. See Speiser v. Randall, 357 U.S. 513 (1958). 
Court continues to cite approvingly. ${ }^{37}$ This Section provides a brief overview of major conditional funding cases, shows how the Court has reconciled them, and then shows where voucher programs should fit into the mix.

\section{Unconstitutional Conditions: An Overview of Major Cases}

The classic example of the unconstitutional conditions doctrine is Speiser v. Randall..$^{38}$ In Speiser, the Court invalidated a California law that conditioned veterans' property tax exemptions on a declaration by the beneficiary disavowing a belief in overthrowing the U.S. government by force, violence, or other unlawful means. The Court held that the condition was essentially a penalty: "To deny an exemption to claimants who engage in certain forms of speech is in effect to penalize them for such speech., 39

The Court has struck down a number of laws by applying this same principle, often by a 5-4 vote. In FCC v. League of Women Voters, the majority held unconstitutional a federal statute that prohibited noncommercial educational stations receiving public broadcast grants from editorializing. ${ }^{40}$ Applying a form of heightened scrutiny, the Court invalidated the restriction, finding that the law was aimed at a form of speech that lay at the "heart" was not narrowly tailored to serve the government's interest. ${ }^{42}$

In another 5-4 decision, Rosenberger v. Rector \& Visitors of the University of Virginia, the Court applied the unconstitutional conditions doctrine to require a state university to provide funds to a Christian student group for its religious magazine. ${ }^{43}$ The University of Virginia had created a Student Activities Fund "to support a broad range of extracurricular student activities ... related to the educational purpose of the University." 44 The Appropriations Committee for the Fund denied a Christian student group's request for reimbursement for printing costs on the ground that the publication was "religious activity." 45 The Supreme Court found that in establishing the Fund, the University had created a limited public forum. The Court did not question that a state could confine such a forum of its own creation to the "limited and legitimate purposes for which it was

37. Rust v. Sullivan, 500 U.S. 173 (1991), cited with approval in United States v. Am. Library Ass'n, 123 S. Ct. 2297, 2309 (2003) (plurality opinion), and Legal Servs. Corp. v. Velazquez, 531 U.S. 533, 540-43 (2001).

38. 357 U.S. 513.

39. Id. at 518 .

40. 468 U.S. 364 (1984).

41. Id. at 381 .

42. Id. at 389 .

43. 515 U.S. 819 (1995).

44. $I d$. at 824 (internal quotation marks omitted).

45. Id. at 827 . 
created... [and] reserv[e] it for certain groups or for the discussion of certain topics." 46 But once the state has opened a limited forum, it "may not exclude speech where [the exclusion] is not 'reasonable in light of the purpose served by the forum,' nor may it discriminate against speech on the basis of its viewpoint." ${ }^{, 4}$ Exclusion of the Christian group was impermissibly viewpoint-based.

In 2001, the Court handed down yet another 5-4 decision in this area of jurisprudence, invalidating a federal law that prohibited lawyers receiving funds from the federal Legal Services Corporation from participating " in any ... way, in litigation, lobbying, or rulemaking, involving an effort to reform a Federal or State welfare system.", 48 The Velazquez Court found that, as in Rosenberger, the government had undertaken to fund private speech in a limited forum, and that it could not engage in viewpoint discrimination within that forum. ${ }^{49}$

One highly controversial First Amendment case, Rust v. Sullivan, stands in sharp conflict with the cases just described. ${ }^{50}$ Rust involved a challenge to a federal regulation that prohibited private family-planning services receiving federal funds from providing "“counseling concerning the use of abortion as a method of family planning or provid[ing] referral for abortion as a method of family planning." "S1 Recipients of government funds could discourage abortion (indeed, they had to) but they were prohibited from engaging in activities that "encourage, promote or advocate abortion.",52 The five-Justice majority found no First Amendment problem with the regulations, noting that "the government may 'make a value judgment favoring childbirth over abortion, and ... implement that judgment by the allocation of public funds." "53 In so doing, the Court explained, "the Government has not discriminated on the basis of viewpoint; it has merely chosen to fund one activity to the exclusion of the other." ${ }^{, 54}$ This last sentence was particularly striking (and arguably nonsensical), considering that the "activity" to which the Court referred involved speech of a specific viewpoint.

46. Id. at 829 .

47. Id. (quoting Comelius v. NAACP Legal Def. \& Educ. Fund, Inc., 473 U.S. 788, 806 (1985)).

48. Legal Servs. Corp. v. Velazquez, 531 U.S. 533, 538 (2001) (quoting Omnibus Consolidated Rescissions and Appropriations Act of 1996, Pub. L. No. 104-134, § 504, 110 Stat. $1321,1321-53)$.

49. Id. at 545 .

50. 500 U.S. 173 (1991); cf. Maher v. Roe, 432 U.S. 464 (1977) (upholding, in the face of an equal protection challenge, a restriction on government funding of abortions).

51. Rust, 500 U.S. at 179 (quoting 42 C.F.R. $\S 59.8(a)(1)$ (1989)).

52. Id. at 180 (quoting 42 C.F.R. $\S 59.10(\mathrm{a})$ ).

53. Id. at 192-93 (quoting Maher, 432 U.S. at 474).

54. Id. at 193. 


\section{Reconciling the Government-Funding Cases}

The Court belatedly reconciled Rust with other conditional funding cases by finding that Rust formed a special category of "government speech" cases to which a different First Amendment analysis applied. In Rosenberger, the Court, citing Rust, explained that "[w]hen the government disburses public funds to private entities to convey a governmental message, it may take legitimate and appropriate steps to ensure that its message is neither garbled nor distorted by the grantee." 55 That is, "when the government appropriates public funds to promote a particular policy of its own it is entitled to say what it wishes," even if it is using private speakers to transmit its message. ${ }^{56}$ The restrictions at issue in Rosenberger were not of this kind, wrote Justice Kennedy, because the University was not itself "speak[ing] or subsidiz[ing] transmittal of a message it favor[ed] but instead expend[ing] funds to encourage a diversity of views from private speakers." ${ }^{, 57}$ Writing for the majority in Velazquez, Justice Kennedy again stressed this distinction between government messages and private messages in striking down the restrictions placed on lawyers receiving funds from the government's Legal Services Corporation:

Although the LSC program differs from the program at issue in Rosenberger in that its purpose is not to "encourage a diversity of views," the salient point is that, like the program in Rosenberger, the LSC program was designed to facilitate private speech, not to promote a governmental message. ..

.. In this vital respect this suit is distinguishable from Rust. $^{58}$

The rationale Justice Kennedy articulated in Rosenberger and Velazquez to distinguish them from Rust was not at all apparent when Rust was decided. Justice Kennedy acknowledged as much in Velazquez: "The Court in Rust did not place explicit reliance on the rationale that the counseling activities of the doctors under Title $\mathrm{X}$ amounted to governmental speech; when interpreting the holding in later cases, however, we have explained Rust on this understanding.",59

Recasting Rust in this light allows us to make more sense out of that decision. Contrary to what the Court said in Rust, the government did

55. Rosenberger v. Rector \& Visitors of the Univ. of Va., 515 U.S. 819, 833 (1995) (citing Rust, 500 U.S. at 196-200).

56. Id.

57. Id. at 834 .

58. Legal Servs. Corp. v. Velazquez, 531 U.S. 533, 542-43 (2001) (quoting Rosenberger, 515 U.S. at 834).

59. Id. at 541 . 
engage in viewpoint discrimination by choosing "to fund one activity to the exclusion of another." ${ }^{60}$ This viewpoint-based funding decision could be sustained, however, because "the government [was using] "private speakers to transmit information pertaining to its own program.",61 In contrast to Rosenberger and Velazquez, the government in Rust had not created a forum to facilitate private speech. ${ }^{62}$

\section{Do Voucher Schools Engage in Government Speech?}

Do voucher programs fall into this government-speech category carved out by the Supreme Court? ${ }^{63}$ One might argue that states institute voucher programs for the very purpose of diversifying the educational messages and approaches available to the state's children and parents. Characterized in this manner, a voucher program would not amount to government speech, but would more closely resemble a forum like the Student Activity Fund in Rosenberger. On the other hand, states could characterize voucher schools as participants in a government program and transmitters of the government's educational message. This characterization likens a voucher program to the government funding in Rust.

The latter characterization is more appropriate. Like the federal law in Rust, voucher laws provide funding to private institutions not to facilitate private messages but rather to provide a specific service to the public-a

60. Rust, 500 U.S. at 193.

61. Velazquez, 531 U.S. at 541 (quoting Rosenberger, 515 U.S. at 833).

62. The Court in some cases has differentiated constitutional and unconstitutional conditions by focusing on the divisibility of the funded program. For example, the Rust Court claimed that the challenged law's burden on speech was minimal because Title X grantees could continue to engage in abortion-related speech as long as those activities were kept "separate and distinct from Title X activities." 500 U.S. at 196. This distinguished Title X from the law at issue in cases like League of Women Voters, where broadcasters could not divide and separate their activities in any way that would permit them to legally editorialize while receiving federal funds. See FCC v. League of Women Voters, 468 U.S. 364, 400 (1984). The divisibility distinction also helps explain Regan v. Taxation With Representation, where the federal government conditioned a tax exemption for nonprofit organizations on a requirement that they forego lobbying activities. 461 U.S. 540 (1983). The Court in Regan upheld the condition, noting that nonprofit groups could still engage in lobbying by dividing themselves in two and having only one of the organizations engage in lobbying. Id. at 544 .

Divisibility, however, no longer seems to be a decisive factor in determining the constitutionality of a condition. Recent cases addressing conditions on funding do not directly discuss the divisibility factor identified in Regan and League of Women Voters. See United States v. American Library Ass'n, 123 S. Ct. 2297 (2003) (plurality opinion); Velazquez, 53I U.S. 533.

63. It should be emphasized that voucher schools are the subsidized entities whose actions the government is regulating. Money may go directly to the parents, who then can choose the participating school on which to spend it. But the channel the money follows is less important than its ultimate destination, and the fact that parents receive the voucher first does not change the fact that the schools are regulated beneficiaries of government assistance. See Grove City Coll. v. Bell, 465 U.S. 555 (1984) (upholding direct regulations on schools even though the money passed first through the hands of students); id. at 565 ("The economic effect of direct and indirect assistance often is indistinguishable."). 
service that by definition must include messages of a very particular kind. The scope of the program and its messages are defined by statute. In Ohio, for example, participating voucher schools are expected to adhere to detailed curricular requirements. Unless granted a special exemption, schools must teach a specified number of units in traditional subjects including English, the fine arts, health, mathematics, science, American history, and American government. ${ }^{64}$ In Wisconsin, private voucher schools must provide a "sequentially progressive curriculum of fundamental instruction in reading, language arts, mathematics, social studies, science and health." 65

The limited scope of these programs is comparable to the limited scope of the Title X program at issue in Rust. Title X authorized grants not so that clinics could provide a broad variety of services to indigent patients, but rather so that clinics could specifically provide "family planning methods and services," which the law defined as including "natural family planning methods, infertility services, and services for adolescents." While Title X's requirements do not appear quite as detailed as some voucher law requirements (such as Ohio's), this only demonstrates that voucher programs are even more like "government speech" than the Rust program itself. $^{67}$

Both voucher programs and Title $X$ contrast sharply with government programs that facilitate the communication of independent, private messages, and that the Court has consequently refused to categorize as government speech. In League of Women Voters, for example, the government had sought to promote the expression of a "wide variety of views on matters of public importance," and even to encourage the "vigorous expression" of controversial ideas. ${ }^{68}$ The same can be said of the University Student Activities Fund in Rosenberger: The whole purpose of the program, as stated by Justice O'Connor, was to create a "free and robust marketplace of ideas." ${ }^{\circ 9}$ To this end, the University permitted a tremendous

64. See OHIO REV. CODE ANN. $\$ 3313.976($ A)(3) (Anderson 2002); OHIO ADMIN. CODE $\S 3301-35-04$ (Supp. 1985). Some states might adopt more flexible requirements. Florida, for example, does not specify the precise contours of the required curriculum. Even in Florida, however, voucher schools must at least follow a curriculum "adopted by an appropriate nonpublic school accrediting body." FLA. STAT. ANN. $§ 1002.38(4)(f)$ (West, WESTLAW through 2003 Reg. Sess. \& Spec. Sess. A-D).

65. WIS. STAT. ANN. $§ 118.165(1)(d)$ (West 1999).

66. 42 U.S.C. $\S 300$ (a) (2000).

67. The argument here is not that private schools (or Title $\mathrm{X}$ clinics) are state actors. The schools and clinics remain private actors, but the government enlists their voluntary support to communicate its own message and provide a specific service.

68. FCC v. League of Women Voters, 468 U.S. 364, 375, 397 (1984). The prohibition on editorializing did not ban controversial content or viewpoints; it only precluded the stations from presenting such viewpoints as their own, rather than those of another person. Id. at 397 .

69. Rosenberger v. Rector \& Visitors of the Univ. of Va., 515 U.S. 819, 850 (1995) (O'Connor, J., concurring). 
variety of messages; funded groups included the Gandhi Peace Center, the Federalist Society, Students for Animal Rights, the Lesbian and Gay Student Union, and the C.S. Lewis Society. ${ }^{70}$ Similarly, in Velazquez, the government program at issue did not require the transmission of specific messages. The government's Legal Services Corporation provided indigent clients with legal assistance in noncriminal matters of essentially any kind. ${ }^{71}$ The breadth of all of these programs made it impossible for the government to plausibly claim that the funded speech and messages were its own. These programs are thus incomparable to Title $\mathrm{X}$ or voucher programs, through which the government funds services and messages with a specified content.

At least one scholar analyzing this issue has come to the opposite conclusion. Mark Tushnet has argued that voucher programs more appropriately fit the Rosenberger line: "Like the fund in Rosenberger, voucher programs make public money available to parents who can choose to send their children to schools whose curricula - their speech-range widely."72 As I have demonstrated, this argument overstates the degree to which state voucher programs seek a diversity of viewpoints. Contrary to what Tushnet implies, states with voucher programs do not seem interested in promoting a wide array of educational messages and curricula, but rather have very specific lessons that they wish to communicate. States seek the participation of private schools in their programs not because they wish to abandon traditional educational goals, but because many public schools have failed to achieve those goals. Certainly, a state might tolerate a limited variety of speakers and pedagogical approaches among those who participate in the voucher program, but this is no different from the federal government tolerating a diversity of doctors and medical techniques in the Title X program at issue in Rust. The presence of diverse speakers does not by itself convert the government's speech into private speech. In the case of both vouchers and Title X programs, many different sorts of speakers may participate in the program and the students or patients may be exposed to a broad array of approaches and viewpoints, but that does not change the fact that the government has enlisted the private speakers-whether they are doctors or schools - to provide a specific public service and convey specific government messages.

Ira Lupu and Robert Tuttle agree that voucher programs are distinguishable from Rosenberger-like programs, and they defend this position by appropriately focusing on purpose: "[T] he provision of public services-even if they have an expressive component-is conceptually

70. Brief for the Petitioners at 4-5, Rosenberger (No. 94-329).

71. Legal Servs. Corp. v. Velazquez, 531 U.S. 533, 536 (2001).

72. Tushnet, supra note 2, at 19. 
distinct from the creation of a forum for debate." 73 In a public forum, "the state provides resources for the very purpose of association and expression, [while] school choice programs have the narrower and more focused purpose of delivering educational service to the young in the community."74

Although the argument for including voucher programs within the Rust paradigm seems compelling, it is obviously impossible to predict what the courts might do in a concrete case. In the unpredictable, often "result-oriented" "75 realm of unconstitutional conditions, the "categorization of the status of a speaker will ordinarily be a very specific, context-bound judgment. ${ }^{, 76}$ One can still conclude, nevertheless, that the most analytically sound understanding of voucher programs places them in the category of "government speech through private actors," an area where the state has significantly more leeway to exclude messages that are incompatible with its goals.

If courts accept this analysis, then antidiscrimination requirements would sail past any First Amendment challenge. By prohibiting discrimination, the state is not interfering with private expression, but is rather making a Rust-like "value judgment" that favors nondiscriminatory and inclusive messages in government-sponsored activity. The government is saying, essentially, that discrimination against certain groups sends a divisive message, grounded in intolerance, that is incompatible with the civic values and worldview that it seeks to instill in youth through publicly funded elementary and secondary education.

\section{Counterarguments to the Government-Speech Argument}

There remain some important counterarguments to consider. First, one might argue that it is not appropriate to apply a government-speech analysis to an expressive association case. Expressive association, one could say, is not pure speech; it is more like conduct. That is, what is protected in expressive association cases like Boy Scouts of America $v$. Dale is not the right to speak or write certain words, but the right to determine membership in an organization. This is different from Rust, where the government only tried to control what words the doctors spoke (or wrote) to their patients. Thus, while the government can control the spoken or written messages that it communicates through private organizations, that does not necessarily

73. Lupu \& Tuttle, supra note 2 , at $980-81$.

74. Id. at $980-81$.

75. Steven D. Hinckley, Your Money or Your Speech: The Children's Internet Protection Act and the Congressional Assault on the First Amendment in Public Libraries, 80 WASH. U. L.Q. 1025, 1071 (2002).

76. Post, supra note 35 , at 156. 
mean the government can also tell those organizations whom to admit or hire.

This argument collapses under its own weight. To the extent that determinations about membership are conduct and not expression, the First Amendment expressive association problem disappears, and the discriminating schools are left without a constitutional basis for their claims. In other words, if the counterargument is correct in maintaining that determinations of membership are not expressive, then schools have no basis for claiming that government policies relating to membership violate their free speech rights in the first place. One must remember that the right to expressive association is a First Amendment right; it is protected because it is expressive. ${ }^{77}$ Claiming that laws relating to admissions policies are not speech would actually seem to undermine the discriminatory schools' constitutional case against antidiscrimination policies. Indeed, if control over admissions policies is not expressive, then Dale was incorrectly decided. For this reason, discriminatory schools may not even push this argument. The schools should know that if it is expressive when they decide who is admitted, then it is also expressive when the government decides. ${ }^{78}$

Another counterargument to the government-speech analysis would rely on Zelman v. Simmons-Harris, the 2002 case in which the Supreme Court held that allowing parents to use school vouchers at religious schools did not violate the Establishment Clause. ${ }^{79}$ In Zelman, it was of vital importance to the majority's constitutional argument that the parents were acting as constitutional circuit breakers between the state and the private religious schools. ${ }^{80}$ That is, Ohio's voucher program did not violate the Establishment Clause because it was parents and students, not the state, who made the decision whether to give money to religious schools. This would seem to suggest that the government is not "speaking" in voucher

77. See Boy Scouts of Am. v. Dale, 530 U.S. 640, 647-48 (2000); Roberts v. U.S. Jaycees, 468 U.S. 609,623 (1984). The Supreme Court has also recognized a nonexpressive right of "intimate association" that is protected not by the Free Speech Clause, but as a liberty under the Due Process Clause of the Fourteenth Amendment. But the right to intimate association would not be implicated in a voucher antidiscrimination case; it extends only to associations that are "highly personal." Roberts, 468 U.S. at 618. The personal relationships best exemplifying this right to intimate association, the Court has explained, are "those that attend the creation and sustenance of a family - marriage, childbirth, the raising and education of children, and cohabitation with one's relatives." Id. at 619 (citations omitted). For an explanation of the difference between "intimate association" and "expressive association," see id. at 617-18.

78. It is of no significance that the cases relating to government speech-or to public fora-have not involved expressive association claims. The right of expressive association is, after all, a newly invigorated right. Before Dale, it was asserted in few Supreme Court cases, and it prevailed in almost none. See, e.g., City of Dallas v. Stanglin, 490 U.S. 19 (1989); N.Y. State Club Ass'n v. City of New York, 487 U.S. 1 (1988); Bd. of Dirs. of Rotary Int'l v. Rotary Club, 481 U.S. 537 (1987); Roberts, 468 U.S. 609. But see Hurley v. Irish-Am. Gay, Lesbian \& Bisexual Group, 515 U.S. 557 (1995).

79. 536 U.S. $639(2002)$.

80. See id. at 653 . 
programs at all; for if the government were making the decision to fund religion, it would violate the Establishment Clause (and Zelman would have come out the other way). ${ }^{81}$

This counterargument, however, fails to account for the differences between speakers and speech; it falsely assumes that because a private actor's speech may be governmental in one aspect, it must also be so in all others. To the contrary, the government's decision to direct specific speech through a private actor-in this case, voucher schools-does not convert all speech of that actor into government speech. The state may use voucher schools to convey certain educational messages (and the state may forbid acts that contradict that message), but the state does not thereby compel all aspects of voucher education. Antidiscrimination regimes in voucher schools may thus remain government speech, even as the government remains indifferent to the religious or nonreligious nature of those schools in order to avoid Establishment Clause problems.

\section{Regulation of Voucher Programs as Limited Public or Nonpublic Fora}

Even if courts find that voucher programs do not fit into the government-speech model, they should still not invalidate antidiscrimination requirements that states attach as conditions for participation. Under the tests formulated by the Supreme Court in government-funding cases, these antidiscrimination policies should survive First Amendment scrutiny.

When the government provides property or funding for private expressive activity, restrictions on that expressive activity are subject to varying degrees of scrutiny, depending on the nature of the "forum" that the government has created. Restrictions are most constitutionally suspect in traditional and designated public fora. "Traditional" public fora are those public spaces-such as parks and streets-that "by long tradition or by government fiat have been devoted to assembly and debate." government can exclude speakers from these fora "'only when the exclusion is necessary to serve a compelling state interest and the exclusion is narrowly drawn to achieve that interest." 83 "Designated" public fora are those that the government opens " for expressive activity by part or all of the public." 84 The exclusion of a speaker "who falls within the class to

81. Daboll, supra note 2, at 727-28.

82. Cornelius v. NAACP Legal Def. \& Educ. Fund, Inc., 473 U.S. 788, 802 (1985) (quoting Perry Educ. Ass'n v. Perry Local Educators' Ass'n, 460 U.S. 37, 45 (1983)).

83. Ark. Educ. Television Comm'n v. Forbes, 523 U.S. 666, 677 (1998) (quoting Cornelius, 473 U.S. at 800$)$.

84. Id. (quoting Int'l Soc'y for Krishna Consciousness, Inc. v. Lee, 505 U.S. 672, 678 (1992)). 
which a designated public forum is made generally available" will be subject to strict scrutiny. ${ }^{85}$

It is obvious, largely for the reasons discussed in the previous Section, that voucher programs do not fall into either of these categories. Voucher programs are not created for any sort of speaker, nor are they even created for any sort of school. ${ }^{86}$

Voucher programs could, on the other hand, be reasonably labeled "limited public fora" or "nonpublic fora." A limited public forum is, as its name implies, a forum opened by the government to a limited class of people for limited expressive purposes. ${ }^{87}$ The Student Activity Fund in Rosenberger was such a forum. A nonpublic forum is government property (or funding) provided for certain individuals or organizations, but not for purpose of creating a vehicle for public communication. ${ }^{88}$ Airports, military bases, and government charity programs have been deemed nonpublic fora.

It is not necessary to determine whether voucher programs are limited public fora or nonpublic fora, ${ }^{89}$ because the First Amendment analysis is essentially the same in either case: Restrictions must not discriminate on the basis of viewpoint, and they must be reasonable in light of the purpose served by the forum. ${ }^{90}$ Antidiscrimination requirements could easily satisfy this test.

\section{Antidiscrimination Policies Are Viewpoint-Neutral}

It has been well-established by the Supreme Court that antidiscrimination policies are not viewpoint-discriminatory. This may be surprising, since antidiscrimination law serves such obvious expressive functions-as the government-speech argument emphasized-and so clearly disfavors those who disagree with antidiscrimination norms. As I demonstrate below, however, this apparent inconsistency can be explained.

85. Id.

86. In the unlikely event that voucher programs are deemed designated public fora, antidiscrimination requirements should, for the reasons explained in Section II.D, nonetheless survive the scrutiny to which the courts would subject them.

87. See Good News Club v. Milford Cent. Sch., 533 U.S. 98, 106-07 (2001).

88. See Perry Educ. Ass'n v. Perry Local Educators' Ass'n, 460 U.S. 37, 46 (1983).

89. Some courts have found that there is no difference between the two. See DiLoreto v. Downey Unified Sch. Dist. Bd. of Educ., 196 F.3d 958, 965 (9th Cir. 1999); Summum v. Callaghan, 130 F.3d 906, 915 (10th Cir. 1997). In general, there is quite a bit of confusion surrounding the categorization of fora. See Putnam Pit, Inc. v. City of Cookeville, 221 F.3d 834, 842 n.5 (6th Cir. 2000).

90. Good News Club, 533 U.S. at 106-07; Forbes, 523 U.S. at 682; Rosenberger v. Rector \& Visitors of the Univ. of Va., 515 U.S. 819, 829 (1995). Two of the most conservative Supreme Court Justices, Scalia and Thomas, would go even further and find that viewpoint discrimination in the allocation of government funds never violates the First Amendment, provided that the government has not created an open public forum. See Nat'l Endowment for the Arts v. Finley, 524 U.S. 569, 598-99 (1998) (Scalia, J., concurring in the judgment). 
As a preliminary matter, it should be noted that the current Court has unanimously found that antidiscrimination laws "do not, as a general matter, violate the First... Amendment[]."91 This finding is plainly incompatible with the claim that such laws are viewpoint-discriminatory, given that viewpoint-discriminatory laws, as a general matter, do violate the First Amendment. ${ }^{92}$

More importantly, when confronting the viewpoint discrimination question head-on, the Court has expressly stated that antidiscrimination laws are not viewpoint-discriminatory. In Roberts $v$. United States Jaycees, for example, the Court found that Minnesota's law banning discrimination in public accommodations did "not distinguish between prohibited and permitted activity on the basis of viewpoint." 93 The law instead "reflect[ed] the State's strong historical commitment to eliminating discrimination and assuring its citizens equal access to publicly available goods and services," a goal that was "unrelated to the suppression of expression." 94 Other cases have come to similar conclusions. ${ }^{95}$ Boy Scouts of America v. Dale did hold that New Jersey's application of its antidiscrimination law violated the First Amendment, but the Court did not base this decision on a finding of viewpoint discrimination. ${ }^{96}$

While the Supreme Court has made clear that antidiscrimination laws do not constitute viewpoint discrimination, it has not clearly articulated

91. Hurley v. Irish-Am. Gay, Lesbian \& Bisexual Group, 515 U.S. 557, 572 (1995).

92. See Lamb's Chapel v. Ctr. Moriches Union Free Sch. Dist., 508 U.S. 384, 394 (1993).

93. 468 U.S. 609,623 (1984).

94. Id. at 624 .

95. See Bd. of Dirs. of Rotary Int'l v. Rotary Club, 481 U.S. 537, 549 (1987) (stating that a law prohibiting gender discrimination served compelling interests and did not discriminate based on viewpoint); see also Wisconsin v. Mitchell, 508 U.S. 476, 487 (1993) (citing Title VII as a "content-neutral" prohibition of discriminatory conduct).

96. The opinion contained no discussion of viewpoint discrimination. Chief Justice Rehnquist, however, writing for the majority, did make one statement that seemed indirectly to accuse New Jersey of engaging in viewpoint discrimination. At the very end of the opinion, he wrote that "[states are] not free to interfere with speech for no better reason than promoting an approved message or discouraging a disfavored one." Boy Scouts of Am. v. Dale, 530 U.S. 640, 661 (2000). This statement makes little sense in light of the rest of the opinion and the facts of the case. Nowhere in the opinion did the majority suggest that the purpose of the law was to suppress disfavored ideas, much less that this was the only purpose. Nor had the majority voiced any disagreement when it cited the New Jersey court's finding that the law's purpose was to protect against " the destructive consequences of discrimination," $i d$. at 647 (quoting Dale v. Boy Scouts of Am., 734 A.2d 1 196, 1227-28 (N.J. 1999)), a purpose that the Court had previously recognized as viewpoint-neutral, see, e.g., Roberts, 468 U.S. at 623-24. Moreover, if the concluding sentence accurately reflected a belief by the majority that New Jersey's policy amounted to viewpoint discrimination, it is exceedingly odd that the Chief Justice did not mention this anywhere else in his opinion; after all, a finding of viewpoint discrimination would have significantly bolstered the majority's holding. Taken as a whole then, Dale does not support the position that antidiscrimination laws are viewpoint-discriminatory. Indeed, the only appeals court since Dale to consider the viewpoint-discrimination question in the context of a gay rights law concluded that the law was viewpoint-neutral. See Boy Scouts of Am. v. Wyman, 335 F.3d 80, $92-95$ (2d Cir. 2003). 
the reasoning behind this conclusion. As noted, it seems obvious that antidiscrimination policies disadvantage those who disagree with antidiscrimination norms. For example, a law prohibiting racial discrimination in the workplace disfavors employers who wish to profess to their employees that interactions among different races are immoral and unhealthy. Moreover, many legislators may have voted for the antidiscrimination law for the purpose of disfavoring the racist viewpoints held by such employers. But despite the viewpoint-discriminatory purposes and effects of the law, it is inconceivable that the Supreme Court would call the law viewpoint-discriminatory. To do so would uproot antidiscrimination law entirely.

How can we explain this? A first response is that antidiscrimination law does not directly refer to the expression of any viewpoint, but is instead, on its face, a regulation of conduct. The Supreme Court has often emphasized the importance of this distinction. ${ }^{97}$ More importantly, regardless of the content-specific or viewpoint-specific motivations underlying antidiscrimination laws, they can also be independently justified without reference to viewpoint or content. ${ }^{98}$ Specifically, they are justified by the state's content- and viewpoint-neutral interest in preventing the "economic and social harms of discrimination." If a law burdening expressive conduct "can be justified without reference to the content of the expression," 100 it is content-neutral-and therefore viewpointneutral $^{101}$ - for the purposes of constitutional analysis, regardless of other content-specific or viewpoint-specific purposes motivating its enactment. Though this explanation has not been precisely articulated by the Court, it is supported by precedent. ${ }^{102}$

Under this approach, antidiscrimination requirements for voucher schools would be deemed viewpoint-neutral despite the fact that one of their underlying purposes is to disfavor specific discriminatory messages in education. Because these laws also serve the independent,

97. See, e.g., Roberts, 468 U.S. at 623.

98. See R.A.V. v. City of St. Paul, 505 U.S. 377, 389 (1992) (citing City of Renton v. Playtime Theaters, Inc., 475 U.S. 41,48 (1986)).

99. Wyman, 335 F.3d at 94.

100. City of Erie v. Pap's A.M., 529 U.S. 277, 294 (2000) (emphasis added).

101. Viewpoint discrimination is a form of content discrimination. Rosenberger v. Rector \& Visitors of the Univ. of Va., 515 U.S. 819, 829 (1995) ("Viewpoint discrimination is ... an egregious form of content discrimination."). If a law is content-neutral, it is also, by definition, viewpoint-neutral. The reverse, however, is not necessarily true. Viewpoint-neutral laws are not always content-neutral.

102. See, e.g., Pap's A.M., 529 U.S. at 294; Ward v. Rock Against Racism, 491 U.S. 781, 791 (1989) ("A regulation that serves purposes unrelated to the content of expression is deemed neutral, even if it has an incidental effect on some speakers or messages but not others."); Playtime Theaters, 475 U.S. at 47 (finding that a law serving a legitimate interest was not invalid merely because one "motivating factor" may have been a desire to restrict First Amendment rights). 
viewpoint-neutral interest in ensuring that all of the state's children have equal educational opportunity, courts should not find them to be impermissible viewpoint discrimination.

One might object to this analytical approach on the ground that states could disingenuously assert viewpoint-neutral justifications for laws in order to immunize their speech-suppressing policies from constitutional attack. This objection overlooks two key aspects of First Amendment analysis. First, courts do not and would not blindly accept any post hoc justification offered for a law suppressing expressive activity. Second and more importantly, the fact that a law is deemed "viewpoint-neutral" does not immunize it from attack under the First Amendment. Even viewpoint-neutral laws may be unconstitutional if they are unreasonable or if they significantly burden expression. This is precisely what occurred in Boy Scouts of America v. Dale. Thus, if a state were to come up with a plausible viewpoint-neutral purpose for its law, a court would still be free to inquire into whether that purpose justified the burdens on speech imposed by the statute. The burdens in a government-funding case, however, would certainly be small. ${ }^{103}$

\section{Antidiscrimination Policies Are Reasonable}

Under the test for limited and nonpublic fora, viewpoint-neutral restrictions are permissible if they are "reasonable in light of the purpose" served by the forum. ${ }^{104}$

Voucher antidiscrimination policies would most certainly pass this test. The very purpose of voucher programs is to expand and improve educational opportunity for a state's or city's students. A policy requiring that the program be open to all students regardless of race, gender, religion, or other factors is not only "reasonable," but also directly advances the program's purpose by ensuring educational opportunity for all students.

Notably, the only federal appeals court to hear a post-Dale challenge to the exclusion of a discriminatory organization from a government forum upheld the exclusion. In Boy Scouts of America v. Wyman, the Second Circuit Court of Appeals upheld Connecticut's refusal to allow the Boy Scouts of America to benefit from a state-established charity program. The exclusion of the Boy Scouts stemmed from its discriminatory ban on gay members; Connecticut law did not permit state agencies to support organizations that discriminated on the basis of sexual orientation. Judge Calabresi, writing for a unanimous panel, found that Connecticut's

103. See infra Subsection II.D.3.

104. Ark. Educ. Television Comm'n v. Forbes, 523 U.S. 666, 682 (1998); Rosenberger, 515 U.S. at 829 . 
exclusion of the Boy Scouts from this nonpublic forum was both viewpointneutral and reasonable, and therefore constitutional. ${ }^{105}$

\section{Applying Heightened Scrutiny to Voucher Antidiscrimination Policies}

Voucher antidiscrimination policies should not be subject to heightened scrutiny, for they are not "direct[] and immediate[]"106 regulations of expressive conduct (that is, they only apply to those choosing to participate in the program) and they are not viewpoint-discriminatory. Nevertheless, it is conceivable, depending perhaps on the court and the facts of the particular case, that a judge would subject antidiscrimination requirements to some form of heightened scrutiny. A court might believe, for example, that the denial of the subsidy in a given case amounts to a penalty or tax. ${ }^{107}$

There is more than one type of heightened scrutiny that could be applied. One possibility would be the $O^{\prime}$ Brien test. In United States v. $O$ 'Brien, the Court held that "when 'speech' and 'nonspeech' elements are combined in the same course of conduct," government regulation of that conduct is permissible only if it furthers an "important or substantial government interest" that is "unrelated to the suppression of free expression" and if the restrictions on First Amendment freedoms are "no greater than is essential to the furtherance of that interest." 108 Because the practice of discrimination has both expressive and nonexpressive qualities to it, courts may find the O'Brien test appropriate in an antidiscrimination case. ${ }^{109}$

An even stricter form of heightened scrutiny would use the test articulated in Dale. Under this standard, regulations of expressive conduct must serve "compelling" state interests that are unrelated to the suppression of ideas-interests that "cannot be achieved through means significantly less restrictive of associational freedoms.""110 Voucher

105. Boy Scouts of Am. v. Wyman, 335 F.3d 80, 91 (2d Cir. 2003); see also Evans v. City of Berkeley, 127 Cal. Rptr. 2d 696, 702 (Ct. App. 2002) (finding that the City of Berkeley's denial of funds to organizations discriminating against gays and atheists did not violate the First Amendment), review granted, 65 P.3d 402 (Cal. 2003).

106. Wyman, 335 F.3d at 91 (internal quotation marks omitted).

107. See Perry v. Sindermann, 408 U.S. 593, 597 (1972); Speiser v. Randall, 357 U.S. 513, 518 (1958). Consider also FCC v. League of Women Voters, where the Court applied heightened scrutiny to a viewpoint-neutral restriction despite the fact that the restriction could be avoided by simply turning down government funds. 468 U.S. 364, 384, 399-400 (1984).

108. 391 U.S. $367,376-77$ (1968).

109. O'Brien does not apply when the burden imposed "directly and immediately affects associational rights ... that enjoy First Amendment protection." Boy Scouts of Am. v. Dale, 530 U.S. $640,659(2000)$. But a restriction that can be avoided by simply refusing government funding is not direct and immediate. See Wyman, 335 F.3d at 91 (finding that conditional funding, unlike the law in Dale, did not impose a "“direct[] and immediate[]" burden, "since its conditioned exclusion [did] not rise to the level of compulsion" (quoting Dale, 530 U.S. at 658-59)).

110. Dale, 530 U.S. at 648 (quoting Roberts v. U.S. Jaycees, 468 U.S. 609, 623 (1984)). 
antidiscrimination requirements can and should survive either of these difficult tests.

\section{The Compelling Interest in Eradicating Discrimination in Education}

States have a compelling interest in eradicating discrimination in education, an interest that outweighs the minimal burdens on speech imposed by voucher programs' antidiscrimination policies. The compelling nature of the interest is supported by the unique importance of education in our society and the destructive effects of discrimination on the "entire educational process."

At first view perhaps, Boy Scouts of America v. Dale might appear inconsistent with the argument that free speech and expressive association may be burdened when a state claims to have a compelling interest in eradicating discrimination. In Dale, the free speech right of expressive association exempted the Boy Scouts from New Jersey's public accommodations law banning discrimination based on sexual orientation. The Dale Court, however, did not reject the possibility that sufficiently compelling state interests could override free speech associational rights in some contexts. On the contrary, the Court reaffirmed the longstanding principle that the right of expressive association "is not absolute" and can be overridden by regulations that are narrowly tailored "to serve compelling state interests." 112

Unfortunately, the Dale Court failed to articulate what sort of compelling interest would suffice. Indeed, the Dale Court conspicuously evaded that question. Chief Justice Rehnquist, writing for the majority, noted that in previous expressive association cases like Roberts $v$. United States Jaycees ${ }^{113}$ and Board of Directors of Rotary International v. Rotary $C l u b,{ }^{114}$ the Court had found a compelling state interest in eradicating discrimination against women. But Chief Justice Rehnquist avoided a comparison between the compelling interest found in those cases and the compelling interest asserted by Dale. Instead, he distinguished those cases by saying that the enforcement of the antidiscrimination laws in Roberts and Rotary Club did "not materially interfere with the ideas that the organization sought to express." 115 Under this interpretation, Roberts and Rotary Club came out the way they did not because of the states' compelling interest in eradicating gender discrimination, but because the

111. Norwood v. Harrison, 413 U.S. 455, 469 (1973).

112. Dale, 530 U.S. at 648 (internal quotation marks omitted).

113. 468 U.S. 609.

114. 481 U.S. 537 (1987).

115. Dale, 530 U.S. at 657. 
burden on First Amendment rights in those cases was insignificant. But if the burden was insignificant, one wonders why the presence or absence of a compelling interest in those cases was relevant in the first place. The compelling interest inquiry, after all, only becomes necessary when there is a demonstrated burden on expression. ${ }^{116}$ The Dale majority's logic suggests that the Roberts and Rotary Club Courts reached the compelling interest question unnecessarily. ${ }^{117}$

Having distinguished Roberts and Rotary Club in a way that made their compelling interest inquiries superfluous, the Dale majority left unclear what sort of compelling interest would suffice when there was a demonstrated burden on expression. Of course, the unmistakable holding of Dale is that the state interest in eradicating antigay discrimination in private membership groups ${ }^{118}$ was not sufficiently compelling to override the Boy Scouts' associational rights. But the state interest in eradicating discrimination in education is very different, and the courts should find it compelling enough to override a voucher school's right to discriminate.

The Supreme Court has long recognized that education plays a uniquely important role in society and that discrimination in education is especially pernicious. The most famous case standing for these principles is, of course, Brown v. Board of Education, in which the Court called education

116. See Lyng v. Int'I Union, 485 U.S. 360, $364-67$ (1988) (holding that because the challenged statute did not "directly and substantially interfere" with First Amendment associational rights, heightened scrutiny did not apply (internal quotation marks omitted)).

117. With regard to Rotary Club, Chief Justice Rehnquist's interpretation is most likely correct. The Rotary Club Court did not purport to rest its decision on a compelling interest justification; it merely stated that "[e]ven if" the law in question worked "some slight infringement" on the Rotary members' First Amendment rights, the infringement was justified by the state's interest in eliminating sex discrimination. 481 U.S. at 549. The Dale majority's reading of Roberts, on the other hand, is more surprising, and probably incorrect, since in that case the Court developed the compelling interest argument more fully and seemed to rely more heavily on it. See Roberts, 468 U.S. at 623-26 (describing the state's compelling interest and explaining that "[b]y prohibiting gender discrimination in places of public accommodation, the Minnesota Act protects the State's citizenry from a number of serious social and personal harms").

118. It is apparent that the Court considered the Scouts a distinctly private group and that the Justices were very troubled by the New Jersey law's characterization of the organization as a "public accommodation." See Dale, 530 U.S. at 657. It is thus unsurprising that the Court did not believe that a consideration of the state interest in eradicating discrimination in public accommodations was important for deciding the case. See id. at 644 ("The Boy Scouts is a private, not-for-profit organization ...."); id. at 652 (quoting a position statement issued by the Scouts in which the organization described itself as a "private, membership organization"); id. at 656-57 (calling New Jersey's public accommodations law "extremely broad"); id. at 657 (stating that the New Jersey Supreme Court had, in applying the law to the Boy Scouts, "applied its public accommodations law to a private entity"); $i d$. at $657 \mathrm{n} .3$ (observing that "[f]our State Supreme Courts and one United States Court of Appeals ha[d] ruled that the Boy Scouts is not a place of public accommodation" and that "[n]o federal appellate court or state supreme court-except the New Jersey Supreme Court in this case-ha[d] reached a contrary result"). It is also telling that Justice O'Connor referred to the Boy Scouts as a "purely private organization" at oral arguments in order to distinguish the Scouts from other groups that had been held to antidiscrimination laws. Transcript of Oral Argument, Dale (No. 99-699), 2000 U.S. Trans. LEXIS 44, at *29. 
"the very foundation of good citizenship."119 The unanimous Court observed: "Compulsory school attendance laws and the great expenditures for education both demonstrate our recognition of the importance of education to our democratic society. It is required in the performance of our most basic public responsibilities...."120 The Court reaffirmed these principles three decades later in Plyler $v$. Doe, even as it acknowledged that education was not actually a "fundamental right" guaranteed to children by the Constitution. ${ }^{121}$ The Court stressed that while education may not be constitutionally mandated, "neither is it merely some governmental 'benefit' indistinguishable from other forms of social welfare legislation.... The American people have always regarded education ... [as a] matter[] of supreme importance .... [E]ducation has a fundamental role in maintaining the fabric of our society." 122 The Court cautioned that it could not ignore "the significant social costs borne by our Nation when select groups are denied the means to absorb the values and skills upon which our social order rests." 123

Of course, both Brown and Plyler dealt with public education. They were equal protection cases dealing with discrimination by the state against an entire class of children, so their precise holdings are obviously not directly applicable to the voucher question. Nonetheless, the Court's recognition of education's vital social role is certainly transferable to other areas of law, as is the Court's emphasis on the principle of equal educational opportunity.

In referring to both public and private schools, the Court has repeated on several occasions that "discriminatory treatment exerts a pervasive influence on the entire educational process." 24 The Court has also stated that "legitimate educational function cannot be isolated from discriminatory practices.""125 Given these unequivocal statements, it is not surprising that the Court has upheld the government's authority to refuse support for discrimination in private education, or even to ban it altogether. As discussed above, Runyon v. McCrary upheld the application of a federal

119. 347 U.S. 483,493 (1954).

120. $I d$.

121. 457 U.S. 202, 221 (1982) (citing San Antonio Indep. Sch. Dist. v. Rodriguez, 411 U.S. $1,37(1973))$.

122. Id. (citations omitted).

123. Id.; see also Grutter v. Bollinger, 123 S. Ct. 2325, 2340 (2003) ("[E]ducation [is] pivotal to sustaining our political and cultural heritage [and has] a fundamental role in maintaining the fabric of society.... [E]ducation... is the very foundation of good citizenship." (internal quotation marks and citation omitted)).

124. Norwood v. Harrison, 413 U.S. 455, 469 (1973); see also Allen v. Wright, 468 U.S. 737, 772 (1984) (Brennan, J., dissenting) (citing Norwood, 413 U.S. at 469); Bob Jones Univ. v. United States, 461 U.S. 574, 594 (1983) (same); Gilmore v. Montgomery, 417 U.S. 556, 571 (1974) (same).

125. Bob Jones Univ., 461 U.S. at 593-94 (quoting Norwood, 413 U.S. at 469) (emphasis omitted). 
antidiscrimination law to a private school that only accepted white students. ${ }^{126}$ The Court stated emphatically that "'the Constitution ... places no value on discrimination," and that "while '[i]nvidious private discrimination may be characterized as a form of exercising freedom of association protected by the First Amendment... it has never been accorded affirmative constitutional protections." 127 In Bob Jones University v. United States, the Court upheld the government's refusal of tax-exempt status to Bob Jones University because of the school's racially discriminatory policies. ${ }^{128}$ The Court held that the government had a "fundamental, overriding interest in eradicating racial discrimination in education," including private education. ${ }^{129}$ This interest prevailed over the university's First Amendment claim of free exercise of religion. ${ }^{130}$

These cases are not ambiguous. They indicate that, at a minimum, laws prohibiting racial discrimination in education serve an interest that is sufficiently compelling to override a voucher school's First Amendment right not to associate with a disfavored group. Indeed, if Runyon is still good law, racial discrimination in all private schools is already prohibited by federal law, whether those schools receive vouchers or not. More difficult questions arise, of course, when one confronts discrimination that is not based on race. While there may be an "unbroken line of cases" establishing "beyond doubt" that "racial discrimination in education violates a most fundamental national public policy,"131 the same cannot obviously be said about antigay discrimination, discrimination against the disabled, or even sex discrimination. ${ }^{132}$

Nevertheless, the fact that the Court has not treated all forms of discrimination identically should not limit a state's authority to assert a compelling interest in eradicating all invidious discrimination in education. The important point is that the Court has recognized that education plays a unique and essential role in our society and that discrimination is incompatible with this role. While most of the relevant education cases have dealt with race, the Court has appropriately expressed its disapproval of discrimination in more general terms. ${ }^{133}$

126. 427 U.S. 160 (1976).

127. Id. at 176 (quoting Norwood, 413 U.S. at 470 (alteration in original)).

128. 461 U.S. 574.

129. Id. at 604 .

130. The law of free exercise has undergone major change since the Court decided Bob Jones University, see Employment Div. v. Smith, 494 U.S. 872 (1990), but the Supreme Court has never rejected its language regarding discrimination in education.

131. Bob Jones Univ., 461 U.S. at 593.

132. See United States v. Virginia, 518 U.S. $515,533,534$ n.7 (1996) (stating that "inherent differences" between the sexes may justify differential treatment and explaining that the Court "[did] not question [Virginia's] prerogative evenhandedly to support diverse educational opportunities," including single-sex schools).

133. See, e.g., Bob Jones Univ., 461 U.S. at 593; Norwood v. Harrison, 413 U.S. 455, 469 (1973) ("[L]egitimate educational function cannot be isolated from discriminatory 
Allowing a state to enforce its compelling interest in eradicating nonracial forms of discrimination in education would not require the Court to heighten the level of review it grants to those forms of discrimination in its state action and Equal Protection Clause jurisprudence. It would only require that the Court reaffirm both the singular importance of education in our national life and the states' well-established power to prohibit discrimination in many forms and in many sectors of society. This state power undoubtedly includes fighting non-race-based forms of discrimination that receive low levels of scrutiny from the Court in its Fourteenth Amendment jurisprudence. ${ }^{134}$

\section{Narrow Tailoring}

It is also clear that antidiscrimination requirements are narrowly tailored to serve the compelling interests at stake. These laws do no more than ban the very practice that the state has a compelling interest in prohibiting.

The Supreme Court apparently agrees, because it has not overturned antidiscrimination laws for lack of narrow tailoring. Dale should not be understood as an exception to this practice. In Dale, the state did not have a compelling interest in eradicating the discrimination by private membership groups like the Boy Scouts. Under strict scrutiny, no amount of narrow tailoring can save the law if it does not serve a compelling purpose.

In antidiscrimination cases where the Court has recognized a compelling interest in eradicating a certain kind of discrimination-such as the interest in eliminating discrimination in commercial organizations-the antidiscrimination law has easily survived the "narrow tailoring" inquiry. For example, in upholding the sex discrimination law in Roberts $v$. United States Jaycees, the Court found that the law " "respond[ed] precisely to the substantive problem which legitimately concern[ed]' the State and abridge[d] no more speech or associational freedom than . . . necessary.",135

\section{The Escape Option and the Burden on Speech}

The Supreme Court has not articulated how exactly the weight of a burden on speech fits into its compelling interest test in First Amendment cases. Nevertheless, it is evident from the Court's jurisprudence that the

practices.... [D]iscriminatory treatment exerts a pervasive influence on the entire educational process." (citation omitted)).

134. See Romer v. Evans, 517 U.S. 620, 628-29 (1996); see also infra notes 157-161 and accompanying text (discussing statutory prohibitions on sexual orientation discrimination and the Court's approval of these prohibitions).

135. 468 U.S. 609, 628 (1984) (quoting City Council v. Taxpayers for Vincent, 466 U.S. 789 , $810(1984))$. 
weight of the burden on speech is a significant factor in its analysis. With this in mind, it is clear that school voucher programs can be distinguished from Dale even further.

In a voucher program that prohibits discrimination, the burden on schools' freedom is indisputably small. Schools may simply refuse to accept voucher students and thereby relieve themselves of the government restrictions. Such an easy escape from government regulation was not available in Dale; nor is it necessarily available in all cases where government benefits are given conditioned on adherence to state regulations.

For example, in Legal Services Corp. v. Velazquez, the Court emphasized that the restrictions on attorneys as a condition for government funds placed a "serious and fundamental restriction" on speech that "distort[ed] the legal system."136 The burden was especially pernicious because indigent clients could not just withdraw from the governmentfunded legal program to free themselves of the restrictions; financial necessity made the publicly funded lawyers their only source of information and legal support. ${ }^{137}$ Because the restrictions on both the legal system and the clients were enormous, and because withdrawing from the program was not a viable option, the Court found the law unconstitutional.

The degree of burden on speech has also factored into the Court's analysis in antidiscrimination cases. In holding New Jersey's public accommodations law unconstitutional as applied, the Dale Court repeatedly stressed the burdensome effects of the law on the Boy Scouts' First Amendment rights, stating that the "forced inclusion of Dale would significantly affect [the Boy Scouts'] expression" 138 and that this burden was "direct[] and immediate[]." "139

In contrast, where antidiscrimination laws have imposed only small burdens on speech, the Court has upheld the laws' application. For example, in upholding antidiscrimination laws over First Amendment claims in Board of Directors of Rotary International v. Rotary Club and Roberts $v$. United States Jaycees, the Court referred not only to the state's compelling interest in eradicating sex discrimination, but also emphasized that the burdens on the defendants' free speech rights were minimal. ${ }^{140}$ The Court made comparable arguments in Hishon v. King \& Spalding and Bob Jones University v. United States, finding that even if there was a burden on

136. 531 U.S. 533,544 (2001).

137. Id. at 546.

138. Boy Scouts of Am. v. Dale, 530 U.S. 640, 656 (2000).

139. Id. at 659 .

140. Bd. of Dirs. of Rotary Int'l v. Rotary Club, 481 U.S. 537, 548-49 (1987); Roberts, 468 U.S. at 626 . 
the discriminating entity's speech, it was not excessive in light of the compelling interest. ${ }^{141}$

In Grove City College v. Bell-a case that in many ways might resemble a voucher discrimination case-the Supreme Court again upheld an antidiscrimination policy by citing the minimal burden on speech. ${ }^{142}$ The federal government in that case had demanded that a private college adhere to Title IX's antidiscrimination requirements as a condition of federal financial assistance. As would be the case in many voucher programs, the government assistance was not in the form of direct aid to the school, but rather consisted of "Basic Educational Opportunity Grants" (BEOGs) to students. The college challenged the antidiscrimination requirements on First Amendment grounds, but the majority paid scant attention to this claim:

Grove City's [argument]-that conditioning federal assistance on compliance with Title IX infringes First Amendment rights of the College and its students-warrants only brief consideration.... Grove City may terminate its participation in the BEOG program and thus avoid the requirements of $\S 901(\mathrm{a})$. Students affected by the Department's action may either take their BEOG's elsewhere or attend Grove City without federal financial assistance. Requiring Grove City to comply with Title IX's prohibition of discrimination as a condition for its continued eligibility to participate in the BEOG program infringes no First Amendment rights of the College or its students. ${ }^{143}$

Given that participation by schools in state voucher programs is entirely voluntarily, it should be difficult for schools to argue convincingly that antidiscrimination requirements unduly burden their First Amendment freedoms. Just as in Grove City College, a voucher school that objects to an

141. See Hishon v. King \& Spalding, 467 U.S. 69, 78 (1984); Bob Jones Univ. v. United States, 461 U.S. 574, 603-04 (1983).

142. 465 U.S. $555,575-76(1984)$.

143. Id. (citation omitted); see also Evans v. City of Berkeley, 127 Cal. Rptr. 2d 696, 702 (Ct. App. 2002), review granted, 65 P.3d 402 (Cal. 2003). In Evans, the Califormia Court of Appeal upheld the City of Berkeley's denial of a public subsidy to the Boy Scouts. Rejecting the Scouts' First Amendment claim, the court emphasized that the city's action did not interfere in any significant way with the organization's speech:

Berkeley has not attempted to muzzle anyone's speech, and Berkeley has not ordered appellants to cease discriminating or associating as they please. Berkeley has only prevented appellants from enjoying a certain city subsidy, free rent, unless appellants' program is open to all residents without regard to the barriers created by the types of invidious discrimination Berkeley seeks to discourage.

Evans, 127 Cal. Rptr. 2d at 702-03. 
antidiscrimination requirement - or any other conditions on vouchers - can "terminate its participation ... and thus avoid the requirements."144

On the other hand, if there is evidence that a school will suffer substantial financial costs if it stops accepting voucher students-something that is unlikely for the time being ${ }^{145}$ - a court might find that there is a significant burden on speech. The Grove City College Court did not consider this possibility. Nevertheless, even where a school feels financially pressured to admit voucher students, it still has the final choice over whether to do so, and in this respect the government regulation is fundamentally different from laws like the one in Dale, which provided organizations with no choice as to whether or not to comply.

\section{4. "The Gay Exception": Distinguishing Different Forms of Discrimination}

In speculating about how courts might react to voucher antidiscrimination requirements, it would be naive not to consider the political pressures and personal ideologies that may lead judges to distinguish between various kinds of discrimination. One obvious problem is that some judges may find antigay discrimination perfectly acceptable, or at least less objectionable than other discriminatory practices. Evidence of this attitude is found in the fact that state and federal laws routinely draw distinctions that favor heterosexuals, and courts have been reluctant to question the validity of these distinctions save in the most extreme circumstances. ${ }^{146}$ Indeed, fervently antigay attitudes continue to be espoused by some Justices on the Supreme Court. In one dissenting opinion joined by Chief Justice Rehnquist and Justice Thomas, Justice Scalia discussed the "eminent reasonableness" of basing a state law on bare animus toward homosexuality, and likened animus toward homosexual

144. Grove City Coll., 465 U.S. at 575-76; see also Maher v. Roe, 432 U.S. 464, 475-76 (1977) ("There is a basic difference between direct state interference with a protected activity and state encouragement of an alternative activity consonant with legislative policy. Constitutional concerns are greatest when the State attempts to impose its will by force of law; the State's power to encourage actions deemed to be in the public interest is necessarily far broader." (footnote omitted)).

145. Vouchers are typically available only to low-income parents who previously would have been unable to afford private education. Therefore, if schools choose not to take part in a voucher program because of opposition to antidiscrimination laws, they will probably not suffer a loss of students; the students who are already enrolled do not rely on vouchers anyway.

146. See, e.g., Able v. United States, 155 F.3d 628 (2d Cir. 1998) (upholding a federal law banning openly gay individuals from military service); Lofton v. Kearney, 157 F. Supp. 2d 1372 (S.D. Fla. 2001) (upholding Florida's ban on adoption by gay individuals). Note that the recently decided case of Lawrence v. Texas may alter how courts deal with similar cases in the future. See 123 S. Ct. 2472 (2003). 
conduct to animus toward murder. ${ }^{147}$ Frustrated advocates for gay and lesbian rights sometimes refer to the "gay exception," by which they mean the tendency of courts to twist otherwise unambiguous legal principles in order to exclude gays and lesbians. ${ }^{148}$ Justice Stevens suggested in his Dale dissent-without using those exact words-that such a "gay exception" might be at play: "The only apparent explanation for the majority's holding, then, is that homosexuals are simply so different from the rest of society that their presence alone-unlike any other individual's-should be singled out for special First Amendment treatment."

Whether or not there was a special "gay exception" at play in the Dale decision, it is reasonable to assume that some courts will treat voucher antidiscrimination requirements differently depending on who is targeted for discrimination. These distinctions-at least as they relate to animus-based discrimination-are unfortunate and theoretically unfounded. While nobody denies that African Americans have endured especially horrific forms of discrimination throughout history, other groups have also experienced and continue to experience the injustice of discriminatory laws and social practices. ${ }^{150}$ If a state legislature reasonably believes that irrational or animus-based discrimination is disadvantaging certain classes of people in the all-important area of education, courts ought to respect the state's authority to assert a compelling interest in eradicating that discrimination - an interest that overrides any voucher school's "right" to government benefits.

Distinctions that treat antigay discrimination as a more acceptable form of discrimination are not only on weak theoretical footing, but they are also increasingly on weak legal footing as well. A solid majority of the Supreme

147. See Romer v. Evans, 517 U.S. 620, 644 (1996) (Scalia, J., dissenting); see also Lawrence, 123 S. Ct. at 2491 (Scalia, J., dissenting).

148. See, e.g., JoYCE MuRdoch \& Deb PRICE, COURTIng Justice: Gay MEN AND LESBIANS BEFORE THE SUPREME COURT 13-14, 194, 215-16, 436, 511-12, 524 (2001).

149. Boy Scouts of Am. v. Dale, 530 U.S. 640, 696 (2000) (Stevens, J., dissenting).

150. Those who espouse antigay views would obviously argue that discrimination against homosexuals is analytically distinct from other forms of discrimination. One common argument is that homosexuality pertains to behavior, while race and sex do not. But sexual orientation is not defined by behavior. See Am. Psychological Ass'n, Answers to Your Questions About Sexual Orientation and Homosexuality, at http://www.apa.org/pubinfo/answers.html (last visited Nov. 11,2003 ) ("Sexual orientation is different from sexual behavior because it refers to feelings and self-concept."). Furthermore, race and gender bias often manifests itself as opposition to behavior: An individual might say, for example, that he does not condemn black people or women, but only interracial marriage and women working outside of the home. Another common argument is that genuinely held religious beliefs justify antigay discrimination. But as is commonly known, religion has been used to justify discrimination in all forms. See, e.g., PETER GOMES, THE GOOD BOOK 92-93 (1996) ("Those who wished to challenge the morality of slavery found that they had to challenge both the authority and the interpretation of scripture... [T] he biblical case for slavery was both strong and consistent."). In any event, it is beyond the scope of this Note to defend the civil rights of gays and lesbians in general. The relevant point here is that states should have the discretion to prohibit discrimination they reasonably find to be invidious and harmful, and courts ought to continue their tradition of respecting these legislative judgments. 
Court has now rejected antigay animus as a legitimate basis for a law. In the landmark 2003 case Lawrence v. Texas, ${ }^{151}$ the Court overturned its notoriously antigay precedent Bowers $v$. Hardwick, ${ }^{152}$ a decision that had upheld sodomy laws and had been widely used to justify discrimination against gays and lesbians. ${ }^{153}$ Invalidating Texas's antigay sodomy law under the Due Process Clause, the Court in Lawrence seemed almost to apologize for its ruling in Bowers, stating that the decision had "demean[ed] the lives of homosexual persons" 154 and that gays and lesbians were "entitled to respect for their private lives." 155 Concurring in the judgment, Justice O'Connor emphasized that "[m]oral disapproval of this group [gays and lesbians], like a bare desire to harm the group, is an interest that is insufficient to satisfy rational basis review under the Equal Protection Clause." 156

This is not to say that courts would have to raise the level of scrutiny that they apply to sexual orientation classifications in order to sustain a voucher antidiscrimination law. ${ }^{157}$ Nor would courts somehow have to require states to protect gays and lesbians from private discrimination. Courts must only recognize that state legislatures may reasonably conclude that sexual orientation discrimination is invidious and that the legislatures may therefore proscribe such discrimination in areas such as employment, public accommodations, and education. This would hardly be a radical step. Fourteen states, the District of Columbia, and more than 140 localities have already banned sexual orientation discrimination in the private sector, ${ }^{158}$ and even before Lawrence the Supreme Court made clear that states could enforce such laws without running afoul of the First and Fourteenth Amendments. As Justice Souter explained for a unanimous Court in Hurley v. Irish-American Gay, Lesbian \& Bisexual Group, provisions banning discrimination based on sexual orientation and other factors "are well within the State's usual power to enact when a legislature has reason to

151. 123 S. Ct. 2472.

152. 478 U.S. 186 (1986), overruled by Lawrence, 123 S. Ct. 2472.

153. See Joseph Landau, Ripple Effect: Sodomy Statutes as Weapons, NEW REPUBLIC, June 23, 2003, at 12 .

154. Lawrence, $123 \mathrm{~S}$. Ct. at 2482.

155. Id. at 2484.

156. Id. at 2486 (O'Connor, J., concurring).

157. I believe, however, that they should. For a brief but excellent discussion of why sexual orientation should be a suspect classification in equal protection law, see Watkins v. U.S. Army, 847 F.2d 1329, $1345-49$ (9th Cir. 1988), withdrawn, 875 F.2d 699 (9th Cir. 1989) (en banc).

158. See Human Rights CAMPAign Fund, THE STATE OF THE WORKPLACE FOR GAY, LESBIAN, BISEXUAL AND TRANSGENDERED AMERICANS 2002, at 9-11 (2003), http://www.hrc.org/worknet/publications/state_workplace/2002/sow2002.pdf. The report lists only thirteen states as banning discrimination because it was published before a fourteenth state, New Mexico, approved its antidiscrimination law. See N.M. STAT. ANN. §28-1-7 (Michie Supp. 2003). 
believe that a given group is the target of discrimination, and they do not, as a general matter, violate the First or Fourteenth Amendments." 159

Indeed, not only has the Court spoken approvingly of these antidiscrimination laws, but on one occasion it invalidated a voter attempt to ban them by state constitutional amendment. In Romer v. Evans, the Court struck down Amendment 2, a Colorado state constitutional amendment banning gay rights laws throughout the state. ${ }^{160}$ While the Romer Court did not condemn antigay discrimination using the same powerful language that it has used in racial discrimination cases, it did clearly acknowledge that some forms of antigay discrimination are irrationally based in animus, that states may not engage in such animusbased antigay discrimination, and that state and local governments must be permitted to ban such discrimination in the private sector. ${ }^{161}$

\section{E. A Deferential Approach: Viewpoint Discrimination Is Inevitable}

I have thus far argued that voucher antidiscrimination policies do not violate the Free Speech Clause because they amount to government speech; that even if they do not amount to government speech, they are reasonable, viewpoint-neutral restrictions on a limited public or nonpublic forum; and that even if these arguments are rejected and the antidiscrimination requirements are subject to heightened scrutiny, they should pass that test.

Even if a court were to reject all these arguments and identify antidiscrimination laws in the school context as viewpoint-discriminatory, the court could still avoid a finding of unconstitutionality by adopting the deferential approach of United States v. American Library Ass' $n,{ }^{162}$ National Endowment for the Arts v. Finley, ${ }^{163}$ and Arkansas Education Television Commission v. Forbes. ${ }^{164}$ In these cases, the Supreme Court declined to scrutinize closely content- and viewpoint-based government

159. 515 U.S. 557, 572 (1995). Hurley itself, however, invalidated Massachusetts's attempt to use such a law to force a private organization to allow a gay and lesbian group to carry a banner in its parade. Significantly, the organization did not seek to exclude gays and lesbians from the parade altogether; it merely sought to disallow them from carrying banners with certain messages. Id. at 572-73.

160. 517 U.S. 620 (1996).

161. See id. at 632 (stating that "the amendment seem[ed] inexplicable by anything but animus toward the class it affect[ed]; it lack[ed] a rational relationship to legitimate state interests"); see also id. at 629 ("Amendment 2 bars homosexuals from securing protection against the injuries that... public-accommodations laws address. That in itself is a severe consequence..."); id. at 631 ("[T]he amendment imposes a special disability upon [homosexuals]."); id. at 635 ("Amendment 2 classifies homosexuals ... to make them unequal to everyone else. This Colorado cannot do. A State cannot so deem a class of persons a stranger to its laws.").

162. 123 S. Ct. 2297 (2003) (plurality opinion).

163. 524 U.S. 569 (1998).

164. 523 U.S. $666(1998)$. 
regulation in the subsidy context under the theory that such scrutiny would be "incompatible with the role" of the funded entity. ${ }^{165}$ In the case of private access to public television, for example, the Forbes Court was deferential to government regulations restricting speakers and speech because "broad rights of access for outside speakers would be antithetical, as a general rule, to the discretion that stations and their editorial staff must exercise to fulfill their journalistic purpose and statutory obligations."166 Similarly, in the allocation of public funds to private artists, the Finley Court held that "[a]ny content-based considerations that may be taken into account in the grant-making process are a consequence of the nature of arts funding": Funds would necessarily be distributed "according to the artistic worth of competing applicants," making "absolute neutrality ... simply inconceivable." 167 A plurality of the Court said the same of federally funded libraries in United States v. American Library Ass' $n$. Close judicial scrutiny, Chief Justice Rehnquist wrote for four Justices, is "incompatible with the discretion that public libraries must have to fulfill their traditional missions," since "[p]ublic library staffs necessarily consider content in making collection decisions."

Applying a similar rationale, courts might conclude that close judicial scrutiny is unsuited to a state's regulation of speech in the education context, because such scrutiny "would be antithetical ... to the discretion that [states] must exercise""169 to ensure that adequate education is available to the state's youth. If the state is to provide all students with an adequate education, "“absolute neutrality is simply inconceivable.",170 This deferential approach would most likely ensure that voucher antidiscrimination laws survive a court challenge.

\section{F. A Brief Comparison}

Though each of the above approaches to the free speech problem could lead a court to uphold antidiscrimination requirements, there are some key advantages to the government-speech approach (Section II.B) and the deferential approach (Section II.E). First and most importantly, these approaches provide a solid analytical framework for upholding not only antidiscrimination requirements, but basic curricular requirements as well. They expressly endorse the government's power to favor particular

165. Am. Library Ass' $n, 123$ S. Ct. at 2304.

166. Forbes, 523 U.S. at 673, quoted in Am. Library Ass' $n, 123$ S. Ct. at 2304.

167. Finley, 524 U.S. at 585 (internal quotation marks omitted), quoted in Am. Library Ass 'n, $123 \mathrm{~S}$. Ct. at 2304 .

168. Am. Library Ass' $n, 123$ S. Ct. at 2304

169. Id. (quoting Forbes, 523 U.S. at 673).

170. Id. (quoting Finley, 524 U.S. at 585). 
messages, and thereby provide a rationale for upholding curricular requirements that are, on their face, both content- and viewpointdiscriminatory. Unlike antidiscrimination requirements, curricular requirements cannot be justified without reference to content and viewpoint. ${ }^{171}$ Nevertheless they must be upheld; were they not, voucher programs would be a political impossibility.

Second, the government-speech framework and the deferential approach would allow for more expansive antidiscrimination policies. Because the government can exercise direct control over messages, it can prohibit more than the mere exclusion of protected classes from schools. It can also ban the teaching of hatred or intolerance (a viewpoint-based restriction), as Ohio's and Colorado's voucher programs already do. Under the forum approach and under the heightened scrutiny analyses, these viewpoint-based restrictions would be difficult to justify. Courts could try to uphold them under a compelling interest theory, but even this is problematic, since a finding of viewpoint discrimination normally sounds the death knell for any law.

Finally, the government-speech and deferential approaches would allow courts to avoid some legally difficult and politically explosive questions. For example, courts would not have to confront the tension between antidiscrimination law and the ban on viewpoint discrimination, and they would not have to decide whether eradicating antigay discrimination is a compelling interest.

\section{FREE EXERCISE AND ESTABLISHMENT CLAUSE OBSTACLES TO ANTIDISCRIMINATION REQUIREMENTS}

Additional First Amendment issues arise when the private school in question is a religious institution, since voucher schools might argue that antidiscrimination provisions burden their free exercise of religion or involve an impermissible government entanglement with religion. To the extent that they defend discriminatory policies in their employment of ministerial teachers (that is, teachers whose job it is to teach the faith), religious schools will probably succeed in court. The Religion Clauses do not, however, provide any special protection for religious voucher schools that discriminate against students or nonministerial staff.

In addressing the Free Exercise and Establishment Clause issues raised by antidiscrimination requirements, it is important to emphasize that there are no religious classifications being made. Regardless of whether voucher

171. A requirement that schools teach the history of slavery and the Civil War is a contentbased requirement. A requirement that schools teach that slavery was wrong is a viewpoint-based requirement. 
programs fit the government-speech framework or some other framework, the antidiscrimination regulations in these programs are facially neutral toward religion. Regulations that discriminated against religious schools because of their religious nature would present a different problem and would probably be unconstitutional under the Establishment, Free Exercise, and Equal Protection Clauses. ${ }^{172}$ Antidiscrimination laws, in contrast, are neutral, generally applicable policies.

\section{A. Solving the Religion Problem: Free Exercise, Smith, and Hybrid Rights}

The Free Exercise Clause does not pose an obstacle to most antidiscrimination requirements. This is because states are normally not constitutionally required to provide special accommodations to religious institutions that exempt them from generally applicable laws.

The widely discussed Smith decision is the obvious focal point in this analysis. In Employment Division v. Smith, a divided Supreme Court upheld the government's denial of unemployment benefits to a Native American employee who was fired for illegal peyote use. ${ }^{173}$ The employee claimed that the Free Exercise Clause protected his sacramental use of peyote. In rejecting this claim, the Court emphasized that the law against drug use was not directed at religion, but was instead a " valid and neutral law of general applicability": "[T] relieve an individual of the obligation to comply with ... '[such a law] on the ground that the law proscribes (or prescribes) conduct that his religion prescribes (or proscribes).","174

A straightforward application of Smith to the antidiscrimination requirements of a voucher program would obviously support a finding that the requirements are constitutional. Antidiscrimination laws, like the law in Smith, are not directed at religion, but are "valid and neutral law[s] of general applicability." 175 Two considerations, however, could complicate Smith's application to a voucher program.

First, the Smith Court explained that the Free Exercise Clause might work to ban the application of a neutral, generally applicable law if, in addition to burdening free exercise, the law also interfered with "other constitutional protections, such as freedom of speech." 176 The law at issue in Smith did "not present such a hybrid situation, but a free exercise claim

172. The Supreme Court agreed in May 2003 to consider whether state constitutions that ban aid to religious schools violate the federal Constitution. See Davey v. Locke, 299 F.3d 748 (9th Cir. 2002), cert. granted, 123 S. Ct. 2075 (2003).

173. 494 U.S. 872 (1990).

174. Id. at 879 (quoting United States v. Lee, 455 U.S. 252, 263 n.3 (1982) (Stevens, J., concurring in the judgment)).

175. Id.

176. Id. at 881 . 
unconnected with any communicative activity." 177 This hybrid doctrine makes little sense as it stands now. If the constitutional right to which a free exercise claim is attached already requires strict scrutiny on its own-as a free speech claim might-then it is unclear what role the free exercise claim would play under a hybrid-rights theory. If neither the free exercise claim nor the constitutional right to which it is attached is sufficient by itself to make strict scrutiny necessary, it is difficult to understand why they would make strict scrutiny necessary when they happen to coincide. If the explanation is that the other constitutional right is provided a higher degree of protection when it is religiously motivated, then the doctrine would seem to put religious actors in a constitutionally favored position, in possible violation of the Establishment Clause and the Equal Protection Clause. In any event, if the courts put teeth into Smith's hybrid-rights exception, there is more than a reasonable possibility that the exception will swallow the rule. This is because the vast majority of free exercise claims will arguably contain an expressive component and thus implicate free speech rights.

Countless academics have criticized the hybrid theory, calling it "difficult to make sense of," 178 "unintelligible,", 179 and "patently insupportable." "180 Some scholars have suggested that the hybrid doctrine was created for the sole purpose of distinguishing inconvenient precedent in Smith, and that even in that regard it failed to serve its purpose convincingly. ${ }^{181}$

Lower courts have been equally perplexed by the hybrid idea, with one court of appeals commenting diplomatically that the Supreme Court "has been somewhat less than precise with regard to the nature of hybrid rights," 182 another court of appeals finding it "difficult to delineate the exact contours of the hybrid-rights theory," 183 and a third calling it "completely illogical." ${ }^{84}$ At least two courts of appeals have openly refused to adopt the hybrid approach. ${ }^{185}$

In those cases in which the lower courts have applied the hybrid theory, the doctrine itself has not been necessary to the decision. For example, in cases specifically recognizing free speech/free exercise hybrid claims, the

177. Id. at 882 .

178. Tushnet, supra note 2, at 26.

179. Alan E. Brownstein, Constitutional Questions About Vouchers, 57 N.Y.U. ANN. SURV. AM. L. $119,120(2000)$.

180. The Supreme Court, 1989 Term-Leading Cases, 104 HARV. L. REV. 198, 205 (1990).

181. See, e.g., Michael W. McConnell, Free Exercise Revisionism and the Smith Decision, 57 U. CHI. L. REV. 1109, 1121-22 (1990).

182. Miller v. Reed, 176 F.3d 1202, 1207 (9th Cir. 1999) (internal quotation marks omitted).

183. Swanson ex rel. Swanson v. Guthrie Indep. Sch. Dist., 135 F.3d 694, 699 (10th Cir. 1998).

184. Kissinger v. Bd. of Trs. of Ohio State Univ., 5 F.3d 177, 180 (6th Cir. 1993).

185. See Leebaert v. Harrington, 332 F.3d 134, 143-44 (2d Cir. 2003); Kissinger, 5 F.3d at 180 . 
free speech claims on their own would have been enough to determine the outcome. ${ }^{186}$

Given the utter confusion surrounding this area of the law, it is difficult to know how the hybrid theory would or should be applied to antidiscrimination requirements for voucher schools. Since the "other" right asserted in a voucher case would probably be a free speech right, the most reasonable approach seems to be to analyze the problem under free speech principles. Even if the free exercise claim gives extra force to the free speech claim under a hybrid-rights theory, the response of a state seeking to enforce an antidiscrimination law should be the same compelling interest argument outlined above in Section II.D. That is, the state should argue that it has a compelling interest in eradicating discrimination in education that justifies the small burden that antidiscrimination regulations impose on a school's freedom of religion and expressive association. ${ }^{187}$

\section{B. Solving the Religion Problem: Free Exercise, the Establishment Clause, and the Ministerial Exception}

One cannot help but hope, of course, that the hybrid doctrine will soon be put out of its misery and eliminated altogether. If that were to occur and Smith's central holding were to apply to vouchers, the Religion Clauses issue would be eliminated almost entirely.

There is still another caveat to consider. Several appellate courts have held that Smith does not overrule the judicially created exception to antidiscrimination laws known as the "ministerial exception." The ministerial exception is a doctrine recognized by several circuits that "exempts the selection of clergy from Title VII" on both Free Exercise and Establishment Clause grounds. ${ }^{188}$ In addition to exempting the selection of clergy, the doctrine has similarly exempted the selection of church

186. See, e.g., Chalifoux v. New Caney Indep. Sch. Dist., 976 F. Supp. 659, 667 (S.D. Tex. 1997); Alabama \& Coushatta Tribes v. Trs. of Big Sandy Indep. Sch., 817 F. Supp. 1319, 1334 (E.D. Tex. 1993); see also William L. Esser IV, Note, Religious Hybrids in the Lower Courts: Free Exercise Plus or Constitutional Smoke Screen?, 74 NOTRE DAME L. REV. 211, 228 (1998) (finding that in every one of the successful hybrid free speech/free exercise cases published as of October 1998, the free speech claim "had a sufficient life of its own to warrant" a strict scrutiny analysis).

187. It is worth noting that in Bob Jones University-a pre-Smith decision where the Supreme Court recognized a compelling interest in eradicating racial discrimination in education-the First Amendment right that the University had claimed was a Free Exercise right, yet the compelling interest still overrode it. See Bob Jones Univ. v. United States, 461 U.S. 574, 604 (1983).

188. EEOC v. Catholic Univ. of Am., 83 F.3d 455, 461 (D.C. Cir. 1996). Title VII itself exempts religious organizations from coverage "with respect to the employment of individuals of a particular religion." 42 U.S.C. $\$ 2000$ (e)(1)(a) (2000) (emphasis added). Exemption from Title VII's ban on other forms of discrimination has come only in the form of a court-created ministerial exception. 
employees who, despite not being clergy, nonetheless play a role in teaching matters of faith or who participate in church governance. ${ }^{189}$

Courts have provided various explanations for the exception. The Court of Appeals for the Eleventh Circuit has found that " $t]$ he minister is the chief instrument by which the church seeks to fulfill its purpose" and that "[a]n attempt by the government to regulate the relationship between a church and its clergy would infringe upon the church's right to be the sole governing body of its ecclesiastical rules and religious doctrine." 190 Therefore, even after Smith, applying antidiscrimination law to church ministers would violate Free Exercise. In addition, "applying Title VII to the employment relationship between a church and its clergy would involve 'excessive government entanglement with religion' as prohibited by the Establishment Clause of the First Amendment."191

The Ninth Circuit has also agreed that the application of Title VII to church ministers would violate the Establishment Clause. It has noted that a "church's selection of its own clergy is [a] core matter of ecclesiastical selfgovernance," 192 and that it cannot "imagine an area of inquiry less suited to a temporal court for decision." $" 193$ Though their rationales have differed, many other appeals courts have come to the same ultimate conclusion: The ministerial exception remains. ${ }^{194}$

The exception would allow religious schools to discriminate in the hiring of clerical teachers who, like ministers, are often engaged in spreading the faith and conveying the religion's core teachings to students. Presumably, these schools could discriminate against such teaching staff on any basis because the courts see themselves as constitutionally barred from inquiring into the disputes.

But the ministerial exception is not far-reaching. Courts properly limit the exception to employees whose "primary duties" include "teaching, spreading the faith, church governance, supervision of a religious order, or supervision or participation in religious ritual and worship."195 For employees without such functions, "the particularly strong religious interests surrounding a church's choice of its representative are missing." 196

189. Catholic Univ. of Am., 83 F.3d at 461.

190. Gellington v. Christian Methodist Episcopal Church, Inc., 203 F.3d 1299, 1304 (11th Cir. 2000).

191. Id. (quoting Lemon v. Kurtzman, 403 U.S. 602, 613 (1971)).

192. Bollard v. Cal. Province of the Soc'y of Jesus, 196 F.3d 940, 946 (9th Cir. 1999).

193. Id. at 949 (quoting Minker v. Balt. Annual Conference of United Methodist Church, 894 F.2d 1354, 1357 (D.C. Cir. 1990)).

194. See Catholic Univ. of Am., 83 F.3d 455; Combs v. Cent. Tex. Annual Conference of the United Methodist Church, 173 F.3d 343 (5th Cir. 1999); Young v. N. Ill. Conference of United Methodist Church, 21 F.3d 184 (7th Cir. 1994); Scharon v. St. Luke's Episcopal Presbyterian Hosps., 929 F.2d 360 (8th Cir. 1991).

195. Rayburn v. Gen. Conference of Seventh-Day Adventists, 772 F.2d 1164, 1169 (4th Cir. 1985) (internal quotation marks omitted).

196. Bollard, 196 F.3d at 947. 
As the Ninth Circuit observed, "There is thus no danger that, by allowing [suits by lay employees] to proceed, we will thrust the secular courts into the constitutionally untenable position of passing judgment on questions of religious faith or doctrine." 197

Employing the same reasoning, the Fifth Circuit found that the ministerial exception did not exempt a sectarian Mississippi college from its obligations to nonministerial teaching faculty under Title VII:

[F]aculty members are not intermediaries between a church and its congregation. They neither attend to the religious needs of the faithful nor instruct students in the whole of religious doctrine. That faculty members are expected to serve as exemplars of practicing Christians does not serve to make the terms and conditions of their employment matters of church administration and thus purely of ecclesiastical concern. ${ }^{198}$

A similar rationale should apply to discrimination against students. The agreement of a student with the church's core doctrines or her ability to teach them is not normally relevant to her role at the institution. She is there to receive an education, not to "attend to the religious needs of the faithful" or "instruct [other] students in the whole of religious doctrine." 199 Thus, no religious exception to a voucher antidiscrimination law should be necessary.

Though it has not done so in the context of ministerial exemptions, the Supreme Court has drawn a distinction between regulation of churches and regulation of religious schools. In Bob Jones University, the Court noted that government interference in the affairs of religious schools was less constitutionally problematic than interference with churches, because the schools were not "purely religious institutions" and because the government had heightened interests in the area of education. ${ }^{200}$ This reasoning obviously bolsters the argument for applying antidiscrimination laws to the admissions practices and nonclerical hiring practices of religious voucher schools.

In sum, the ministerial exception may preclude states from imposing antidiscrimination requirements on the clerical hiring decisions of religious voucher schools. ${ }^{201}$ Nonetheless, states would probably still be free to

197. Id.

198. EEOC v. Miss. Coll., 626 F.2d 477, 485 (5th Cir. 1980).

199. Id.

200. Bob Jones Univ. v. United States, 461 U.S. 574,604 n.29 (1983).

201. Yet there is also a possibility that states are not constitutionally permitted to exempt religious schools from antidiscrimination requirements. For a discussion of these issues in the context of charitable choice legislation, see Laura B. Mutterperl, Note, Employment at (God's) Will: The Constitutionality of Antidiscrimination Exemptions in Charitable Choice Legislation, 37 HARV. C.R.-C.L. L. REV. 389, 391 (2002). 
require adherence to antidiscrimination norms in the admission of students and in the hiring of nonministerial staff. ${ }^{202}$

\section{CONCLUSION}

Some might have speculated that the Court's powerful endorsement of vouchers in Zelman v. Simmons-Harris would move the voucher battle out of the courts and into the legislatures. As this Note demonstrates, however, there are still important legal questions to be resolved. The discrimination question is likely to be one of the most hotly contested of them, and courts may have difficulty making sense of the doctrine that governs the First Amendment issues.

In this Note, I have sought to demonstrate that antidiscrimination laws, as applied to voucher schools, can and should survive a First Amendment challenge. The Free Speech Clause argument has several prongs. First, courts should find voucher laws to be Rust-like programs in which the government speaks through private actors. In such cases, the state may make value judgments and distinguish among viewpoints without having its decisions subject to strict scrutiny under the First Amendment. Second, even if courts find that voucher programs are not analogous to Rust but instead resemble a nonpublic or limited public forum, antidiscrimination requirements should be deemed a reasonable restriction on that forum. Furthermore, if the antidiscrimination policies are subjected to heightened scrutiny, they still can and should survive. Finally, even if the policies are deemed viewpoint-discriminatory, they can be upheld under the deferential approach of American Library Ass' $n$.

Though it may seem counterintuitive, the free exercise problems raised by voucher antidiscrimination policies are less difficult to address. Smith made clear that the Free Exercise Clause does not provide an exemption

202. Mark Tushnet discusses the possibility of an additional Establishment Clause problem. He explains that antidiscrimination requirements may lead to unconstitutional "sect preferences." Because some schools "will refuse to participate in programs with conditions inconsistent with their faith commitments," they will not benefit from the voucher program to the same extent as other schools with different faith commitments. In Tushnet's view, this may amount to government preference among sects in violation of the Establishment Clause. See Tushnet, supra note 2 , at 28 .

I believe that Tushnet exaggerates the Establishment Clause problem. Voucher antidiscrimination policies are facially neutral - not only "as between religiously affiliated schools and secular ones," id., but also as among various religions. Tushnet does not adequately take account of this second form of neutrality. Moreover, the incidental disparate impact that the antidiscrimination policies have on some religions is no different from the disparate impact that any law has on religious groups that disagree with it. As we have seen, the Supreme Court has analyzed such laws under the Free Exercise Clause, not the Establishment Clause, and it has not subjected such laws to strict scrutiny. See Employment Div. v. Smith, 494 U.S. 872 (1990). Tellingly, Tushnet does not cite any court precedent in this section of his Establishment Clause argument. See Tushnet, supra note 2, at 27-28. 
from neutral laws of general applicability, and antidiscrimination laws unquestionably fit into this category of law. There are only two caveats. First, discriminatory religious schools might raise "hybrid" free speech/free exercise claims. Such claims have not prevailed in the courts, however, when the free speech claim was not sufficient to determine the case on its own. Second, the ministerial exception will make inquiries into religious employment decisions impossible, but this exception will not--and should not-protect a school's right to discriminate against students or nonministerial faculty and staff.

While civil rights groups should certainly be troubled by the current lack of comprehensive antidiscrimination protections in voucher legislation, they should not assume that vouchers will necessarily lead to state-funded discrimination protected by the Constitution. The weight of precedent supports the states' power to prohibit discrimination in voucher schools. The "right" to discriminate may not be as expansive as many fear it to be. 